\title{
The shrews (Cryptotis) of Colombia: What do we know about them?
}

\author{
Elkin A. Noguera-Urbano', Javier E. Colmenares-Pinzón², Johana Villota ${ }^{3}$, Abelardo Rodríguez-Bolaños ${ }^{4}$ and Héctor E. Ramírez-Chaves ${ }^{5 *}$ \\ ${ }^{1}$ Instituto de Investigación de Recursos Biológicos, Alexander von Humboldt. Avenida Paseo Bolívar (Circunvalar) 16-20, Bogotá, \\ D. C. Colombia. Email: elkalexno@gmail.com (EAN-U). \\ ${ }^{2}$ Grupo de Estudios en Biodiversidad, Laboratorio de Ecología, Escuela de Biología, Universidad Industrial de Santander, Carrera \\ 27 \# 9, Bucaramanga, Santander. Colombia. Email: javiercolmenaresbiologo@gmail.com (JEC-P). \\ ${ }^{3}$ Grupo de Ecología del Paisaje y Modelación de Ecosistemas ECOLMOD, Maestría en Ciencias, Universidad Nacional de Colombia. \\ Carrera 45 \# 26-85, Bogotá, D. C. Colombia. Email: johavi13@gmail.com (JV). \\ ${ }^{4}$ Grupo de Investigación Biodiversidad de Alta Montaña, Universidad Distrital Francisco José de Caldas, y Laboratorio de Ecología \\ Funcional, Programa de Doctorado, Universidad Javeriana, Bogotá, D. C. Colombia. Email: mountainresearch@gmail.com (AR-B) \\ ${ }^{5}$ Departamento de Ciencias Biológicas, and Centro de Museos, Museo de Historia Natural, Universidad de Caldas, Calle 65 \# 26-10, \\ Manizales, Caldas. Colombia. Email: hector.ramirez@ucaldas.edu.co (HER-C). \\ *Corresponding autor
}

In Colombia, shrews (Cryptotis) are represented by seven species associated with Andean, high Andean, and Paramo ecosystems of the three national Cordilleras. Of these species, five are endemic to the Andean region of the country. Despite representing the group of mammals with the highest rate of endemic species, the knowledge currently available on aspects such as natural history, distribution, and ecology is limited. This work assesses the current state of knowledge of the shrews of Colombia, discusses taxonomic issues, risks and threats related to conservation, and identifies research needs and priorities. We compile the information on shrews of Colombia available in the literature and databases. We include two of the known species of the country and one to be determined within a phylogenetic context. In general, the knowledge of the shrews of Colombia reveals the lack of ecological and genetic studies. There are unsolved taxonomic questions about the presence of certain species in the different mountain ranges of the country. There is an urgent need to generate molecular information to clarify the richness of the genus in Colombia which, according to our observations, has been underestimated. The knowledge about the shrews of Colombia is still scarce, even when some species were first described more than a hundred years ago. The need to conduct systematic studies and comprehensive morphological descriptions to clarify the richness of the shrews of Colombia is highlighted.

En Colombia, las musarañas (Cryptotis), están representadas por siete especies asociadas a ecosistemas andinos, altoandinos y paramunos de las tres cordilleras nacionales. De estas especies, cinco son endémicas de la región andina del país. A pesar de representar el grupo de mamíferos con mayor porcentaje de especies endémicas, el conocimiento que tenemos sobre aspectos como historia natural, distribución y ecología, es casi nulo. Este trabajo evalúa el estado actual de conocimiento de las musarañas de Colombia, discute problemas taxonómicos, riesgos y amenazas para su conservación e identifica necesidades y prioridades de investigación. Compilamos la información disponible en literatura y bases de datos sobre las musarañas de Colombia. Ubicamos a 2 de las especies conocidas en el país y una por determinar en un contexto filogenético. La tendencia general en el conocimiento de las musarañas de Colombia es hacia la ausencia de estudios ecológicos y genéticos. Además, aún persisten dudas taxonómicas con respecto a la presencia de ciertas especies en las diferentes cordilleras del país. Existe una necesidad urgente de generar información molecular para clarificar la riqueza real del género en Colombia que, de acuerdo con nuestras observaciones, ha sido subestimada. El conocimiento sobre las musarañas de Colombia es aún precario, a pesar de que algunas especies fueron descritas hace más de cien años. Se resalta la necesidad de generar estudios sistemáticos y de profundizar en descripciones morfológicas más completas que permitan clarificar la riqueza de musarañas presentes en Colombia.

Key words: Andes; distribution; endemism; Eulipotyphla; Soricidae; taxonomy.

C 2019 Asociación Mexicana de Mastozoología, www.mastozoologiamexicana.org

\section{Introduction}

South American shrews (Eulipotyphla: Soricidae: Cryptotis) represent an adaptive radiation of small mammals that live in mountain ecosystems, displaying the highest richness in northern South America (Woodman and Péfaur 2008). In Colombia, a country located in the northwest of South America, seven species are currently recognized (Cryptotis brachyonyx, C. colombianus, C. medellinius, C. perijensis, C. squamipes, C. tamensis, and C. thomasi), five of which are endemic to different sectors of the Andean region of the country (Woodman and Péfaur 2008; Solari et al. 2013; Ramírez-Chaves et al. 2016). The number of species registered in Colombia has nearly doubled over the past 30 years (by 1986, three confirmed species had been recorded and another one was considered as likely present; Cuervo Diaz et al. 1986), and the number of endemic species has almost tripled (by the year 2000, only two species were considered endemic, C. colombianus and C. squamipes out of a total of four recorded and one likely present species; Alberico et al. 2000).

In addition to the seven species recorded in the country, the likely presence of $C$. mera in Colombia has been suggested (Cuervo Diaz et al. 1986: as Cryptotis nigrescens) given its proximity to the records from Darien in Panama (Alberico et al. 2000; Cuartas-Calle and Muñoz Arango 2003; Woodman and Péfaur 2008). Another species whose 
presence has been suggested in Colombia is C. equatoris, which may be found in the Andes in southwest Colombia, department of Nariño, near Ecuador (Ramírez-Chaves and Noguera-Urbano 2011). However, records confirming its presence with respect to the current taxonomic proposals have not been validated yet; therefore, this species has been excluded from the recent lists of mammals of Colombia. Separately, it has been mentioned that C. squamipes may be a complex of at least three species restricted to Colombia (Woodman and Péfaur 2008). These facts indicate that the richness of Cryptotis in Colombia may have been underestimated.

The conservation status of shrews in Colombia has been evaluated from a global perspective; no regional assessments are currently available, despite the fact that at least five species are endemic to the country. The potential threats that shrews currently face are diverse, especially considering that these mammals are associated with the Andean region - one of the areas with the highest alteration rates by deforestation (70 to $93 \%$ of the original area), with high concentrations of human settlements (Cavelier and Etter 1995; Rangel 2000) and a high susceptibility to climate change. In addition, this area supports the highest concentrations of human settlements in Colombia (Armenteras et al. 2003).

At a country level, none of the shrews is listed as a threatened species (MADS 2014; 2017). However, C. brachyonyx (listed globally as Data Deficient DD; Woodman 2008a) is considered as probably extinct or restricted to microhabitats inadequately sampled (Woodman and Péfaur 2008) since it has only been recorded in two localities (Woodman, 2003; 2008a).

In Colombia, the genus Cryptotis represents an important target group for research at various scales, given its large number of endemism and current threats. For this reason, this work aims to set the grounds for further studies in Colombia. To this end, this paper reviews, for each species recorded in the country, the current state of knowledge, distribution, risks and threats related to conservation, and research needs and priorities.

\section{Materials and Methods}

State of knowledge. We gathered the published literature available (articles, chapters in books, proceedings, and thesis) including information on the shrews of Colombia since the description of the first species in 1897 to 2018. This information was organized according to the following categories: a) Type of publication (journal articles, conference proceedings, book chapter, book, thesis). b) Relevance for the study (general, specific). c) Overview (summary papers with no new information). d) Research topics: I) Anatomy and Morphology. II) Taxonomy and Systematics. III) Biogeography, Current Distribution, and Records (we only considered lists of species that included data not previously available in other publications). IV) Threats and Relation- ship with Humans / Conservation (threats, conservation, cultural aspects). V) Ecology and Natural History (abundance, behavior, predation, diet, reproduction, habitat use). VI) Genetics. The keywords used in searches under different combinations included: Colombia + Blarina, Cryptotis, avia, avius, brachyonyx, colombiana, colombianus, medellinia, medellinius, perijensis, squamipes, tamensis, thomasi. We report the available information for each species according to the topics searched.

Research Needs and Priorities. To define research priorities, we calculated the "research effort" (adapted from Andrade-Ponce et al. 2016) by assigning a score based on the number of topics investigated for each species (Categories I to VI based on the current state of knowledge). The maximum score in this category was 60 , which is the sum of each topic in the literature that obtained a score of 10 if a species had at least 10 studies for that topic. If the species had less than 10 studies, the score of each topic was calculated as the sum of the number of studies for that species. Thus, species with no published information for a given topic were scored as zero for that topic, while species with information in at least one publication for the six topics obtained a score of 6 . Low research effort scores $(<30)$ or $<5$ for each individual topic point to high research needs.

Distribution. We searched different sources of information to derive an approximation of the areas of distribution of shrews in Colombia. These included the Information System on Colombian Biodiversity, an initiative that provides open access on the biodiversity of Colombia (SiB Colombia; https://sibcolombia.net/el-sib-colombia) and the Global Biodiversity Information Facility database (GBIF; http:// www.gbif.org). The search considered the genus, specific name of the species, and Colombia (GBIF 2018; https://www. gbif.org/occurrence/search?q=Cryptotis\&country=CO; doi 10.15468/dl.hjv2ad). We also reviewed the records available in Woodman and Péfaur (2008) and the distribution maps published in the Red List of the International Union for the Conservation of Nature (IUCN 2018; https://www. iucnredlist.org). These were used to construct a map of species richness by overlaying the distribution areas of each species. All the geographic analyzes were conducted using the "raster" and "sp" packages (Hijmans 2018) (Pebesma and Bivand 2005) in R (R Development Core Team 2018) and ArcMap (ESRI 2016).

Molecular Characterization of Some Species and their Phylogenetic Relationships. No genetic information is currently available for the Colombian species of Cryptotis. Hence, the Cytochrome b (Cytb) mitochondrial marker was characterized for some species; it has been used repeatedly in studies addressing systematics, taxonomy, and phylogeography (Guevara and Cervantes 2014; Moreno-Cárdenas 2017; Zeballos et al. 2018). Tissues were obtained from three specimens from different localities throughout the country. The first corresponds to $C$. thomasi, collected in the department of Cundinamarca and deposited in the Collection of Mammals of Instituto de Ciencias Naturales (ICN) under collector 
number YMS 31 (no catalogued). The second, identified as C. squamipes, was collected in the municipality of El Tambo, department of Cauca, and deposited in the Collection of Mammals of the Museum of Natural History at Universidad del Cauca (MHNUC 1572). The third was collected as part of the Santander BIO Project in the municipality of Santa Bárbara, department of Santander, and deposited in the Collection of Mammals of the Museum of Natural History at Universidad Industrial de Santander (UIS-MZ 1594). The taxonomic identity of the third specimen (UIS-MZ 1594) is uncertain, as it does not display all the morphological traits of the species recorded in the area (C. tamensis, C. meridensis), so that this work refers to it as Cryptotis sp.

Genomic DNA was extracted from approximately 25 mg of tissue (preserved in $96 \%$ ethanol), using the "GeneJet Genomic DNA Purification Kit" (Thermo-Scientific), following the manufacturer's specifications. Cytochrome $B$ (1,140 bp) was amplified with primers MVZ05 (5'-CGA AGC TTG ATA TGA AAA ACC ATC GTT G; Smith and Patton 1993) and H15915 (5'-AAC TGC AGT CAT CTC CGG TTT ACA AGA

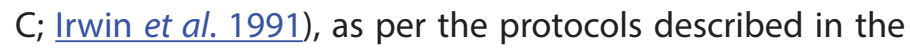
work of Guevara and Cervantes (2014). PCR reactions were carried out in a Multigene TC9600-G Thermal Cycler (Labnet International, Inc.). The success and quality of PCR reactions were confirmed by viewing the products in $0.8 \%$ agarose gels using the EZ-VISION fluorescent agent (AMRESCO, Inc.). Those amplified fragments with the highest intensity and the expected band size were sent to the "Sequencing and Molecular Analysis Service" (SSiGMol) at Universidad Nacional de Colombia. These were purified and sequenced in a $3500 \mathrm{ABI}$ sequencer (Applied Biosystems). The inspection of electropherograms, as well as the edition, and assemblage of consensus from the sequences received (forward and reverse) were carried out with Geneious R11 (Biomatters Limited). To confirm that the material generated represents endogenous DNA of shrews, all consensuses were subjected to comparisons with the BLAST algorithm (Altshul 1990). Consensus sequences were submitted to GenBank under accession numbers MK681774 (Cryptotis sp), MK681775 (C. thomasi), and MK681776 (C. squamipes).

The Cytb sequences for all Cryptotis species available in the GenBank public repository were downloaded, as well as those of external groups used by Guevara and Cervantes (2014) in their analysis (Appendix 1). These sequences were aligned, along with those produced in the present work, using the MUSCLE 3.8.425 (Edgar 2004) algorithm implemented in Geneious R11. The nucleotide evolution model was determined through the best fit to the final matrix using the Akaike Information Criterion (AIC) in the program jModelTest 2.1.10 (Darriba et al. 2012).

A Bayesian inference analysis was run in MrBayes 3.2.6 (Ronquist et al. 2012). To ensure the convergence of topologies, two runs were conducted in parallel, each with four Markov chains that started from trees generated at random and were maintained over 15,000,000 generations, with parameters sampled at 1000 -generation intervals. The stationary phase and convergence were monitored in the Tracer program version 1.6 (Rambaut et al. 2014). Twentyfive percent of sampling points prior to the asymptote were discarded (burn-in), and the remaining trees $(11,250)$ were pooled to calculate the a posteriori probability of clades in a consensus tree. A node was deemed as having significant support when its a posteriori probability was greater than 0.95 (Gutierrez et al. 2017).

Uncorrected average genetic distances ( $p$ ) and the distances corrected according to the Kimura-2-parameter model (K2P; Kimura 1980) were estimated from the complete matrix of sequences in MEGA version 7.0 (Kumar et al. 2015). The values obtained were compared with those reported for the genus Cryptotis by Guevara and Cervantes (2014) and Zeballos et al. (2018).

\section{Results}

State of Knowledge, Research Needs, and Priorities. We found 50 studies on the seven Cryptotis species in Colombia. Of these, $72 \%$ were scientific articles; $10 \%$, books and book chapters; $6 \%$, degree dissertations and thesis; and $12 \%$, electronic documents and conference abstracts. The species with the highest number of studies was Cryptotis colombianus ( $n=16)$ and the least studied was C. perijensis $(n=3)$. The topics most frequently addressed refer to taxonomy and distribution records (Table 1).

The information reviewed indicates uncertainty regarding taxonomic and geographic information related to records of shrews of Colombia available in databases. The search in SiB Colombia showed 191 records in total (Table 2), with 122 corresponding to five species (C. colombianus, C. medellinius, C. meridensis, C. squamipes, and C. thomasi) distributed in Colombia. A total of 56 questionable records were found, representing specimens identified to genus. Seven support the presence of C. meridensis (species distributed in Venezuela) and six that have retained the name C. avia, currently considered as a synonym of $C$. thomasi (Woodman and Péfaur 2008).

GBIF produced 193 records concentrated in the north of the Central and Western Cordilleras (Antioquia and Cundinamarca; Figure 1). The best represented species was C. thomasi $(n=147)$, while two species have no available records in this

Table 1. Research effort on shrews (Cryptotis) of Colombia. The highest possible research effort score is 60. I) Anatomy and Morphology; II) Taxonomy and Systematics; III) Biogeography, Distribution, and Records; IV) Threats and Relationships with Humans / Conservation; V) Ecology and Natural History; VI) Genetics.

\begin{tabular}{lrrrrrrrr}
\hline \multicolumn{1}{c}{ Species } & \multicolumn{7}{c}{ Number of publications by topic } & Effort \\
& I & II & III & IV & V & VI & \\
\hline Cryptotis brachyonyx & 2 & 2 & 2 & 3 & 1 & 0 & 10 \\
Cryptotis colombianus & 6 & 5 & 12 & 2 & 5 & 0 & 28 \\
Cryptotis medellinius & 5 & 4 & 7 & 4 & 7 & 0 & 27 \\
Cryptotis perijensis & 1 & 1 & 1 & 0 & 0 & 0 & 3 \\
Cryptotis squamipes & 3 & 3 & 7 & 3 & 2 & 0 & 18 \\
Cryptotis tamensis & 4 & 4 & 5 & 2 & 3 & 0 & 18 \\
Cryptotis thomasi & 8 & 6 & 10 & 1 & 3 & 0 & 25 \\
\hline
\end{tabular}


Table 2. Geographic information available for shrews of the genus Cryptotis of Colombia from different sources.

\begin{tabular}{lrrrr}
\hline \multicolumn{1}{c}{ Species } & $\begin{array}{c}\text { Woodman and } \\
\text { Péfaur (2008) }\end{array}$ & $\begin{array}{c}\text { SiB Colombia } \\
\text { 2018 }\end{array}$ & GBIF 2018 & $\begin{array}{r}\text { IUCN } \\
2018\end{array}$ \\
\hline Cryptotis brachyonyx & 2 & 0 & 0 & 1 \\
Cryptotis colombianus & 2 & 22 & 16 & 1 \\
Cryptotis medellinius & 4 & 7 & 6 & 1 \\
Cryptotis perijensis & 0 & 0 & 0 & 0 \\
Cryptotis squamipes & 4 & 14 & 12 & 1 \\
Cryptotis tamensis & 3 & 0 & 12 & 1 \\
Cryptotis thomasi & 2 & 79 & 147 & 1 \\
\hline
\end{tabular}

database (C. brachyonyx and C. perijensis). The information proposed by Woodman and Péfaur (2008) indicated that the best represented species are $C$. squamipes and C. medellinius, with four records each. As regards the geographic information available on the IUCN website, six species of shrews are reported for Colombia, except for $C$. perijensis. There are only two localities reported for $C$. perijensis, from which a buffer was drawn around each locality using the disperal distance for a species in the same genus (C. parvus, radius $280 \mathrm{~m}$; Choate and Fleharty 1973). The exploratory analysis of overlapping areas of distribution of shrews showed the probable existence of two areas with sympatric shrews. One is located between Medellín and Manizales, on the Western and Central Cordilleras (C. colombianus and C. medellinius); the second, in the north-eastern hills of Bogotá (C. thomasi and C. brachyonyx, Figure 2). Some species of shrews could

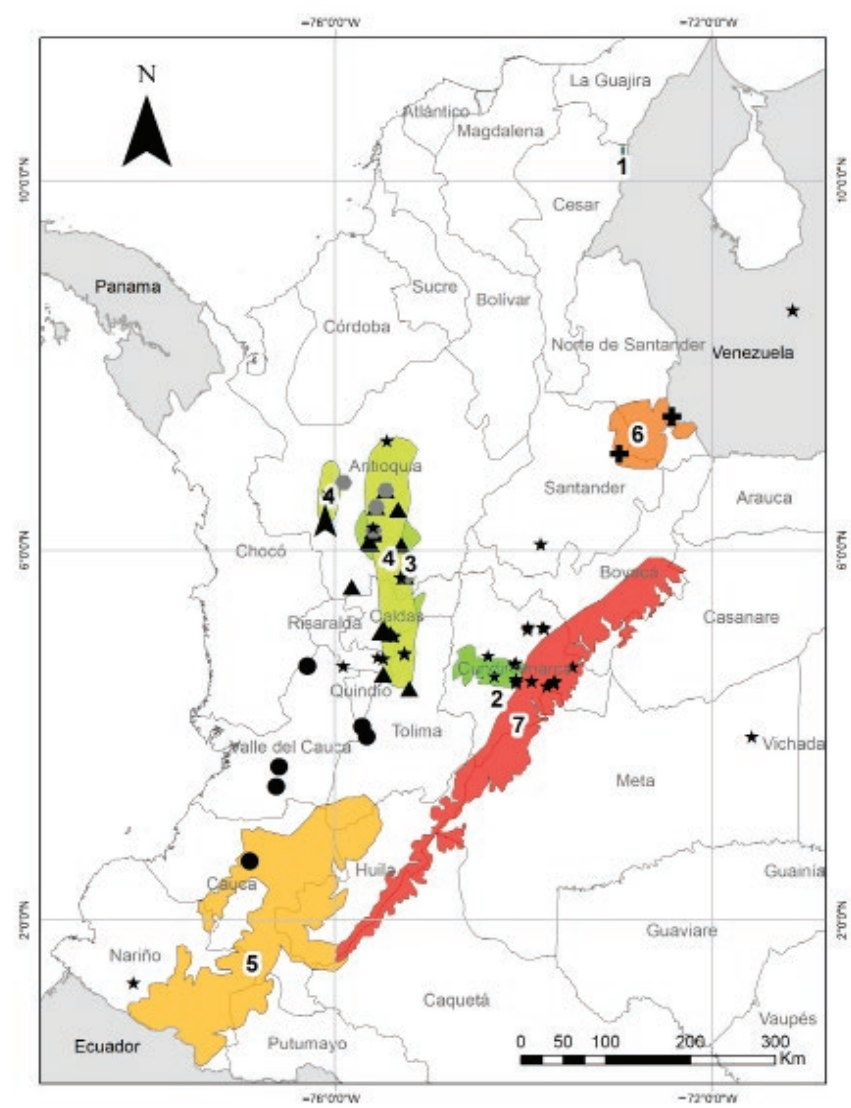

Figure 1. Geographic distribution of shrews in Colombia from IUCN maps (numbers) and GBIF available records (symbols). 1) C. perijensis (no GBIF records). 2) C. brachyonyx (no GBIF records). 3) C. colombianus (triangle). 4) C. medellinius (grey hexagon). 5) C. squamipes (circle). 6) C. tamensis (cross). 7) C. thomasi (star).

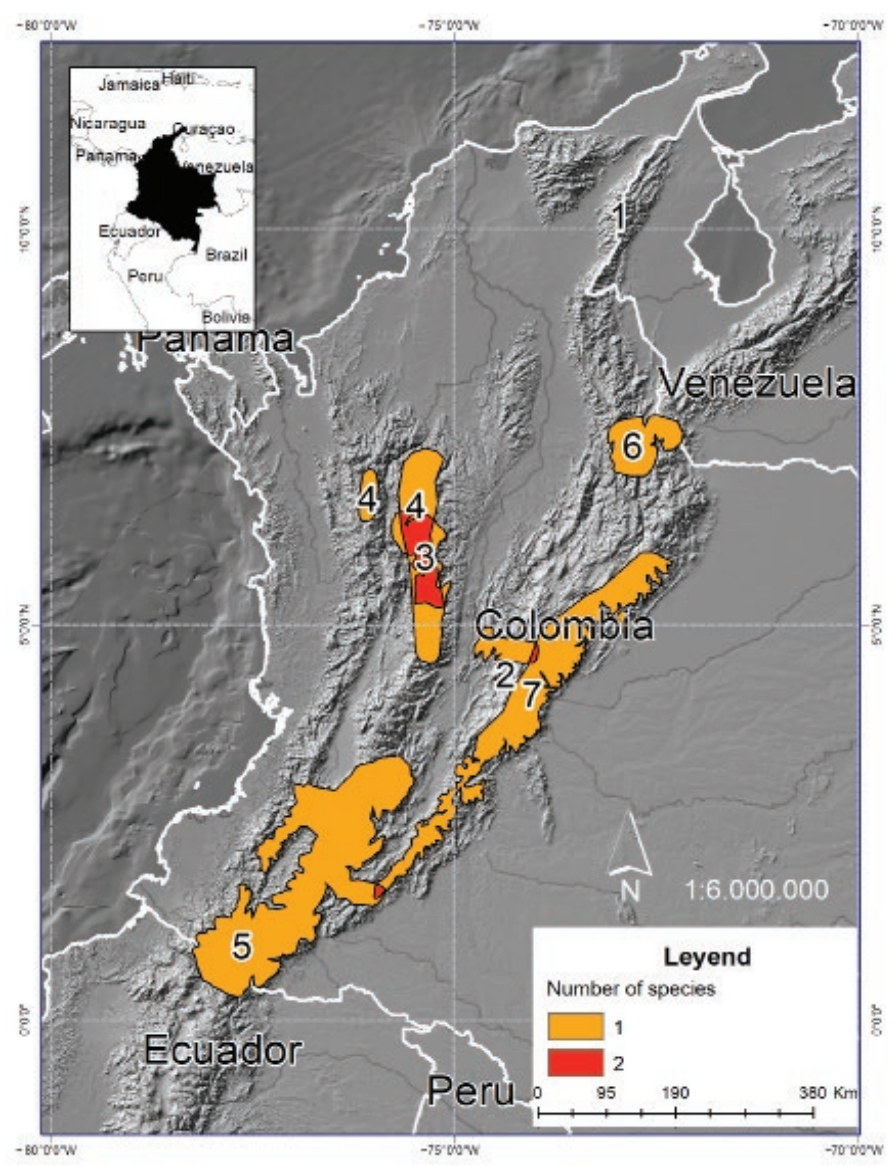

Figure 2. Overlapping areas of distribution of the shrews of Colombia based on the distributions proposed by IUCN (2018). The areas of sympatry of two species are marked in red. Numbers indicate the names of species: 1) C. perijensis. 2) C. brachyonyx. 3) C. colombianus. 4) C. medellinius. 5) C. squamipes. 6) C. tamensis. 7) C. thomasi.

be represented in at least ten conservation areas (Figure 3). The state of knowledge and distribution of the species studied are summarized below.

Cryptotis brachyonyx. It is known from four records obtained throughout more than a century. The latest was obtained in 1925. Although these specimens were initially assigned to C. colombianus (Woodman and Timm, 1993), distributed as two isolated populations in the Central and Eastern cordilleras of Colombia, the reassessment by Woodman (2003) assigned the population of the Eastern Cordillera to C. brachyonyx, and those living in the Central Cordillera to $C$. colombianus. The description was based on the combined analysis of cranial characters, axial skeleton, and external characters. The characters described assign this species within the "nigrescens" group, which also includes $C$. colombianus. The rest of the Colombian shrews belong to the "thomasi" group (Table 3). C. brachyonyx is known only from its original publication (Woodman, 2003) and two additional documents mentioning aspects on its conservation status (Woodman 2008a; Woodman and Péfaur 2008), anatomy, and ecology. C. brachyonyx has a very low research effort, thus having the highest need for research of all species of shrews that are endemic to Colombia (Table 1).

Distribution: Endemic to Colombia. It is known only from two localities in the department of Cundinamarca, 


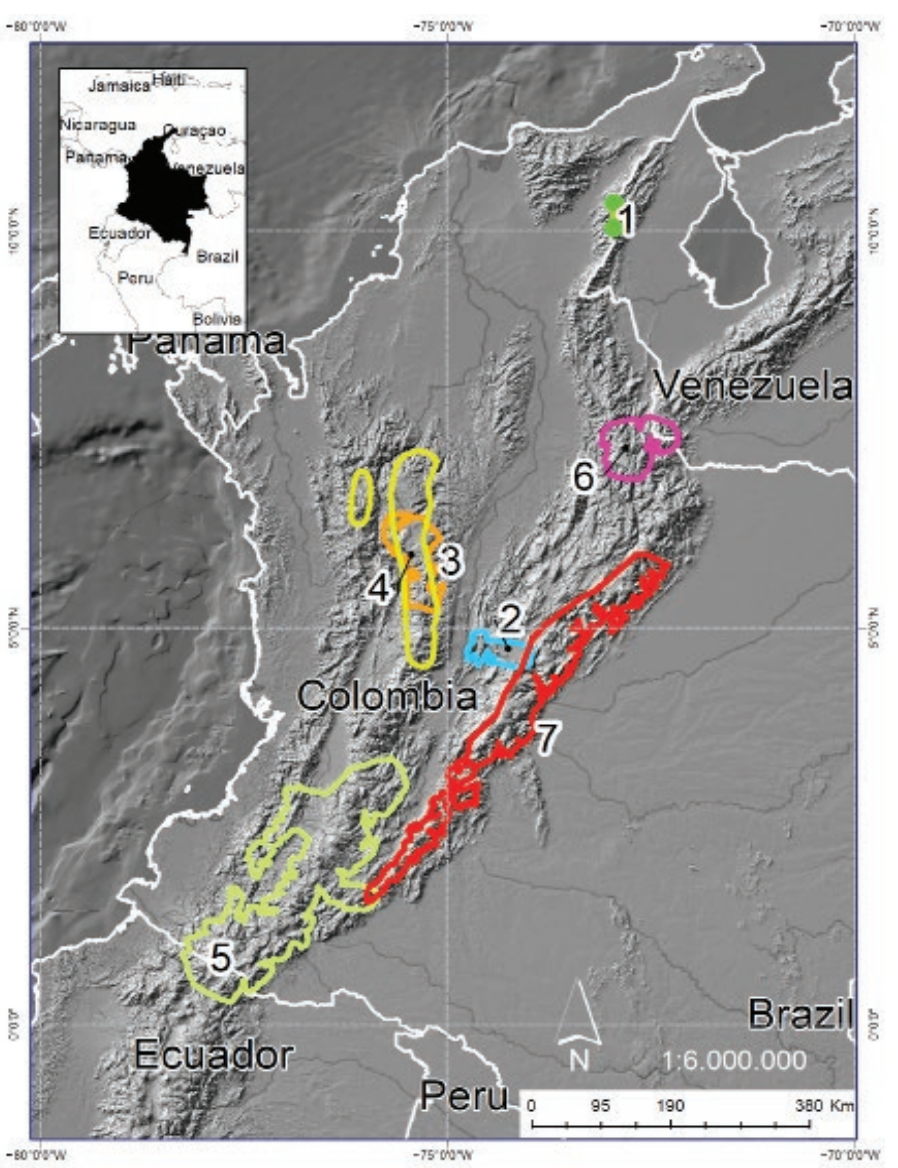

Figure 3. Overlay of the areas of distribution of shrews on conservation areas in Colombia. Numbers indicate the names of species: 1) C. perijensis. 2) C. brachyonyx. 3) C. colombianus. 4) C. medellinius. 5) C. squamipes. 6) C. tamensis. 7) C. thomasi.

Eastern Cordillera, within an elevational range of 1,300 to 2,715 masl. A specimen from San Juan de Rio Seco was previously reported as Cryptotis colombianus (Woodman 1996; Woodman, 2003).

Conservation status: It is listed as Data Deficient at global level (Woodman 2008a).

Cryptotis colombianus was described from a single specimen collected in the Negrito river, Sonsón, Antioquia; there are studies on its anatomy ( 6 studies; Woodman and Timm,
1993; Woodman 1996; Woodman, 2003; Cuartas-Calle and Muñoz Arango 2003; Woodman and Péfaur 2008; Marín Cardona 2009), taxonomy and nomenclature (5; Woodman and Timm, 1993; Vivar et al. 1997; Woodman et al. 2003; Woodman and Péfaur 2008; Marín Cardona 2009), biogeography and current distribution (12; Woodman and Timm, 1993; Woodman 1996; Woodman et al. 2003; Cuartas-Calle and Muñoz Arango 2003; Castaño et al. 2003; Woodman and Péfaur 2008; Marín Cardona 2009; Castaño 2012; EscobarLasso et al. 2013; Solari et al. 2013; 2015; Noguera-Urbano and Escalante 2015; Castaño et al. 2017), threats and conservation (2; Díaz-Pulido et al. 2015; Woodman 2017), ecology and natural history $(5$; Woodman et al. 2003; CuartasCalle and Muñoz Arango 2003; Woodman and Péfaur 2008; Marín Cardona 2009; Solari et al. 2015). It shows a moderate research effort (Table 1).

Distribution: Endemic to Colombia. It is known from the Central Cordillera in the departments of Antioquia, Caldas, and Risaralda, in an elevational range between 1,750 and 2,150 masl (Woodman and Timm, 1993; Woodman et al. 2003; Cuartas-Calle and Muñoz Arango 2003; Castaño 2012; Escobar-Lasso et al. 2013; Solari et al. 2015; Castaño et al. 2017). A specimen from San Juan de Rioseco (Cundinamarca), in the Eastern Cordillera previously reported as Cryptotis colombianus corresponds to C. brachyonyx (Woodman 1996; Woodman, 2003).

Conservation status: It is listed as Least Concern (Woodman 2008b; 2017). It has been listed as threatened in the country (Díaz-Pulido et al. 2015); however, it requires new assessments.

Cryptotis medellinius. It was described based on specimens collected in the northern part of the municipality of Medellín (San Pedro), Colombia (Thomas, 1921). Its description was based on specimens acquired by the British Museum from an exchange with Brother Nicéforo María. According to the original description, the type locality of $C$. medellinius is the municipality of San Pedro, $30 \mathrm{~km}$ north of Medellín (Thomas, 1921). Similar to all shrews of Colom-

Table 3. General morphological characters by group of Cryptotis species of Colombia.

\begin{tabular}{|c|c|c|c|c|}
\hline \multirow[b]{2}{*}{ Species } & \multirow[b]{2}{*}{ Group } & \multirow[b]{2}{*}{ Endemism } & \multicolumn{2}{|c|}{ Date } \\
\hline & & & Collection & Description \\
\hline Cryptotis brachyonyx & C. nigrescens & Yes & 1895 & 2003 \\
\hline Cryptotis colombianus & $\begin{array}{l}\text { The species in this group are considered as having higher mobility capabilities based on the structure } \\
\text { of the humerus, which is less complex and robust, relative to other more fossorial species. (Woodman } \\
\text { and Timm 1993; Woodman et al., 2003). In general, these shrews have small body and forefoot, although } \\
\text { with a proportionally longer tail. These prefer low to medium altitudinal ranges, although it has not been } \\
\text { confirmed for the Colombian species of this group. }\end{array}$ & Yes & 1950 & 1993 \\
\hline Cryptotis medellinius & C. thomasi & Yes & 1920 & 1921 \\
\hline Cryptotis perijensis & $\begin{array}{l}\text { These are the largest South American shrews, although with proportionately shorter tail. The forelimbs } \\
\text { have a more robust general pattern including a more complex humerus and forefoot with wider claws, } \\
\text { interpreted as an adaptation to a more fossorial habit (Woodman and Gaffney 2014). These are considered } \\
\text { as shrews inhabiting higher elevations. }\end{array}$ & No & 1989 & 2015 \\
\hline Cryptotis squamipes & & Yes & 1911 & 1912 \\
\hline Cryptotis tamensis & & No & 1968 & 2002 \\
\hline Cryptotis thomasi & & Yes & 1895 & 1897 \\
\hline
\end{tabular}


bia, the description of $C$. medellinius was based on the morphological analysis of cranial, dental, and external characters (Thomas, 1921). These allocate it within the "thomasi" group; it is larger compared to C. brachyonyx and C. colombianus.

There are studies on its anatomy and morphology (5 studies; Thomas, 1921; Woodman 2002; Cuartas-Calle and Muñoz Arango 2003; Woodman et al. 2003; Woodman and Péfaur 2008), taxonomy and systematics (4; Thomas, 1921; Vivar et al. 1997; Woodman et al. 2003; Woodman and Péfaur 2008), biogeography and current distribution (7; Tate 1932; Sanchez 2000, as C. colombiana; Sánchez and Alvear 2003; Woodman 2002; Woodman et al. 2003; Woodman and Péfaur 2008; Delgado-V 2009; Noguera-Urbano and Escalante 2015), and statements on its ecology and natural history (7; Sanchez 2000, as C. colombiana; Woodman 2002; Sánchez and Alvear 2003; Delgado-V 2002; Cuartas-Calle and Muñoz Arango 2003; Woodman et al. 2003; Woodman and Péfaur 2008). It shows a moderate research effort (Table 1 ).

Distribution: Endemic to Colombia. It is known from the northern part of the Central and Western Cordilleras of Colombia within an elevational range between 1,800 and $3,800 \mathrm{~m}$, in the departments of Antioquia, Caldas, and Risaralda. The southern limit of distribution in each mountain range is uncertain, no specimen has been reported in the southern part of Paso de Quindío in the Central Cordillera nor in the southern part of Páramo de Frontino in the Western Cordillera (Vivar et al. 1997; Woodman 2002; Cuartas-Calle and Muñoz Arango 2003; Woodman and Péfaur 2008; Delgado-V 2009). This species inhabits Premontane Moist Forest, Low Montane Forest, Montane Forest; and Low Montane and Montane Rainforest (Cuartas-Calle and Muñoz Arango 2003).

Conservation status: It is currently listed as Least Concern (Naylor and Roach 2016a). Its vulnerability risk is similar to that of C. colombianus and C. squamipes (Díaz-Pulido et al. 2015). It was previously listed as Data Deficient (Cuartas-Calle and Muñoz Arango 2003).

Cryptotis perijensis. It was described based on a specimen collected in 1989 in the department of Cesar, near Finca El Suspiro, at 2,100 m a.s.l. in northern Colombia (Duarte and Viloria 1992). Since it was described less than four years ago, the knowledge about this species is virtually nil (Table 1). The morphological information and distribution available come from the first record (Quiroga Carmona and Woodman, 2015), according to which it was assigned to C. thomasi (Duarte and Viloria 1992). There is a second record, also identified as C. thomasi (Corredor-Carrillo and Muñoz-Saba 2007) from Serranía del Perijá, between 2,850 and 3,100 masl, near the municipality of San José de Oriente in the department of Cesar, Colombia. The set of morphological traits related to dental and cranial anatomy allowed to assign $C$. perijensis to the "thomasi" group. It shows a very low research effort (Table 1).

Distribution: known in Colombia from two localities in
Serranía del Perijá, department of Cesar, in an elevational range between 2,000 and 3,100 masl (Duarte and Viloria 1992; Corredor-Carrillo and Muñoz-Saba 2007; Quiroga Carmona and Woodman, 2015).

Conservation status: it has not been assessed to date.

Cryptotis squamipes. It was originally described as Blarina (Cryptotis) squamipes based on a single specimen collected at 3,151 masl in the Western Cordillera, $64 \mathrm{~km}$ west of Popayán (currently in the municipality of El Tambo, Cauca) in June 1911. There are studies on its anatomy and morphology ( 3 studies; Allen 1912; Cuartas-Calle and Muñoz Arango 2003; Woodman and Péfaur 2008); taxonomy and systematics (3; Allen 1912; Woodman and Péfaur 2008; Guevara López 2010); biogeography and current distribution (7; Allen 1912; Tate 1932; Cuervo Diaz et al. 1986; Cuartas-Calle and Muñoz Arango 2003; Rivas-Pava et al. 2007; Woodman and Péfaur 2008; Rojas-Díaz et al. 2012), and ecology and natural history (2; Cuartas-Calle and Muñoz Arango 2003; Woodman and Péfaur 2008). The research effort for this species is low (Table 1).

Distribution: Endemic to Colombia. It is known from the following localities: Farallones, Tenerife and Finca Zingara, department of Valle del Cauca, and in Cerro Munchique, department of Cauca, of the Western Cordillera and southern part of the Central Cordillera. It inhabits an elevational range from 1,500 to 3,375 m (Allen 1912; Cuervo Diaz et al. 1986; Woodman and Péfaur 2008).

Conservation status: It is listed as Least Concern (Naylor and Roach 2016b), showing a vulnerability risk similar to that of C. colombianus and C. medellinius (Díaz-Pulido et al. 2015). It was previously listed as Data Deficient (CuartasCalle and Muñoz Arango 2003).

Cryptotis tamensis. It was described based on one specimen collected in 1968 from the locality of Buena Vista, Tachira state, Venezuela, near Serranía de Perijá and Páramo of Tama, municipality of San Cristóbal, department of Norte de Santander, Colombia (Woodman, 2002). C. tamensis has been assigned to the "thomasi" group. In addition, a series of morphological and morphometric traits have been proposed for its taxonomic validation (Woodman, 2002). Studies on this species address its anatomy, morphology, taxonomy, and systematics (4 studies; Woodman, 2002; Cuartas-Calle and Muñoz Arango 2003; Woodman and Péfaur 2008; Estupiñán-Saavedra 2009); biogeography and current distribution (5; Woodman 2002; Cuartas-Calle and Muñoz Arango 2003; Woodman and Péfaur 2008; Estupiñán-Saavedra 2009; Cáceres Martinez et al. 2017), conservation (2; Cáceres Martinez et al. 2017; Woodman and Quiroga-Carmona 2018), and ecology and natural history (3; Woodman 2002; Cuartas-Calle and Muñoz Arango 2003; Woodman and Péfaur 2008). Similar to C. squamipes, the research effort for this species is low (Table 1).

Distribution: In Colombia, the species is known from the upper part of the Táchira river, Páramo de Tamá, municipality of Surata, department of Norte de Santander, and Finca 
El Rasgón, Vereda La Cristalina, municipality of Piedecuesta, department of Santander, in the Western Cordillera. The elevational range is between 2,385 and 3,000 masl (Woodman 2002; Woodman and Péfaur 2008; Estupiñán-Saavedra 2009).

Conservation status: It is listed as Least Concern (Woodman and Quiroga-Carmona 2018). It was previously listed as Data Deficient (Cuartas-Calle and Muñoz Arango 2003).

Cryptotis thomasi was the first valid shrew species for South America (Merriam 1897), initially described as Blarina thomasi. It was described from five of the 10 specimens collected in Hacienda "La Selva" in Sabana de Bogotá in 1895. Studies on this species address its anatomy and morphology (8 studies; Merriam 1897; Allen 1923; Vivar et al. 1997; Woodman 2002; Cuartas-Calle and Muñoz Arango 2003; Woodman and Péfaur 2008; Estupiñán-Saavedra 2009; Vianchá Sánchez et al. 2012), taxonomy and systematics (6; Allen 1923; Woodman 1996; Vivar et al. 1997; Cuartas-Calle and Muñoz Arango 2003; Woodman and Péfaur 2008; Estupiñán-Saavedra 2009), biogeography and current distribution (10; Merriam 1897; Cuervo Diaz et al. 1986; López-Arévalo et al. 1993; Woodman 2002; Cuartas-Calle and Muñoz Arango 2003; Otálora Ardila 2003; EstupiñánSaavedra 2009; Vianchá Sánchez et al. 2012; Liévano Latorre and López Arévalo 2015; Medina et al. 2015), and ecology and natural history (3; López-Arévalo et al. 1993; CuartasCalle and Muñoz Arango 2003; Woodman and Péfaur 2008; Liévano Latorre and López Arévalo 2015). It is one of the species most recorded in the literature, along with C. colombianus and C. medellinius (Table 1).

Distribution: Endemic to Colombia. It is known from the following localities: Parque Natural Municipal Rancheria, municipality of Paipa; Neusa dam and Páramo of Chisacá, in the department of Cundinamarca, central and north-eastern part of the Eastern Cordillera, among other localities in the departments of Boyacá, Cundinamarca, and Santander. It lives in an altitudinal range of 2,800 to $3,500 \mathrm{~m}$. The southern limit of its distribution is located in the northern part of Paso de Las Cruces, department of Huila, and the northern limits are associated to the headwaters of the valleys and tributaries of the Chicamocha and Upía rivers (Woodman 2002; Estupiñán-Saavedra 2009).

Conservation status: It is currently listed as Least Concern (Naylor et al. 2018).

Molecular Characterization of Some Species and their Phylogenetic Relationships. This work characterizes for the first-time species of the genus Cryptotis from Colombia at the molecular level, at least for one mitochondrial marker (Cytb). Sequences comprising almost the entire coding region of the gene were successfully obtained for $C$. thomasi, C. squamipes and a third species whose taxonomic determination has not been solved yet (Cryptotis sp.). The matrix included in the phylogenetic analyses consisted of a total of 114 sequences, with 25 corresponding to the external groups used by Guevara and Cervantes (2014) and 89 to 26 species of the genus Cryptotis (Appendix 1).
In the Bayesian topology retrieved, Cryptotis appears as a monophyletic group with high support $(\mathrm{pp}=1)$, whose sister genus is Blarina (Figure 4). However, some nodes that reflect the deepest phylogenetic relationships, i. e., those between groups of species, tend to show a low level of support. This is in line with previous work using the same marker or a combination of mitochondrial and nuclear markers, which nonetheless failed to achieve a final resolution of the phylogenetic scenario of Cryptotis (Guevara and Cervantes 2014; He et al. 2015; Moreno-Cárdenas 2017).

According to the analysis performed, the species in the "parvus" group form a monophyletic group with high support $(p p=1)$. The monophyly and relationships within the other species remain unclear. This is particularly evident in the "mexicanus" and "goldmani" groups because, although some species form monophyletic subgroups, these appear phylogenetically scattered without a clear association matching the morphological definitions (Figure 4).

Similar to the work of Moreno-Cárdenas (2017), the Bayesian topology obtained here points to a close relationship between the "thomasi" and "nigrescens" groups ( $\mathrm{pp}=$ 0.99), while revealing an unexpected association between these and some members of the "mexicanus" group ( $C$.

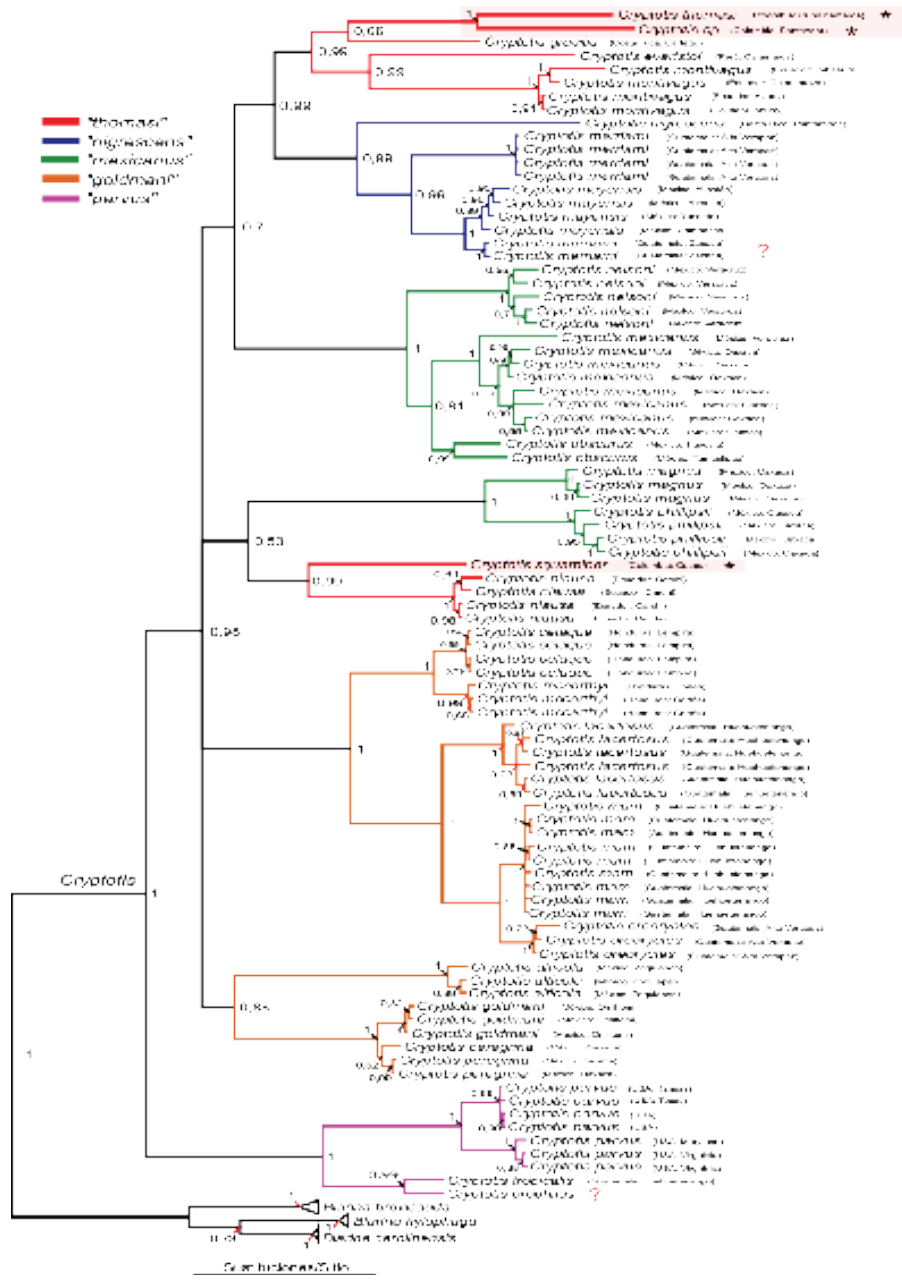

Figure 4. Bayesian Phylogeny of Cytochrome B (Cytb). The new information corresponding to species of Cryptotis of Colombia is marked with asterisks (*). The groups of species were defined based on the work of He et al. (2015). Access numbers of each sequence are listed in Appendix 1. 
Table 4. Percentage of genetic divergence (genetic distances of Cytb corrected according to the Kimura-2-parameter model x 100) between the species of the "thomasi" group (according to the morphological definition), including those of Colombian origin characterized in this work. The divergence values between sibling and geographically close species are highlighted in bold.

\begin{tabular}{llrrrrr}
\hline & Group/Specie & 1 & 2 & 3 & 4 & 5 \\
\hline 1 & Cryptotis thomasi & - & - & - & - & - \\
2 & Cryptotis sp. & $\mathbf{8 . 7} \%$ & - & - & - & - \\
3 & Cryptotis squamipes & $14.6 \%$ & $15.0 \%$ & - & - & - \\
4 & Cryptotis niausa & $14.2 \%$ & $14.4 \%$ & $\mathbf{9 . 8} \%$ & - & - \\
5 & Cryptotis montivagus & $13.5 \%$ & $14.6 \%$ & $14.0 \%$ & $12.4 \%$ & - \\
6 & Cryptotis evaristoi & $13.5 \%$ & $12.9 \%$ & $14.7 \%$ & $13.9 \%$ & $10.6 \%$ \\
\hline
\end{tabular}

nelsoni, C. mexicanus and C. obscurus), although with little statistical support $(\mathrm{pp}=0.70)$. However, the molecular evidence seemingly contrasts the traditional morphological definition of these two groups. On the one hand, all species recovered within the "nigrescens" group were consistent with the morphology (C. nigrescens, C. merriami, and C. mayensis; $\mathrm{pp}=0.99$ ), while the "thomasi" group shows an unexpected pattern of relationships. With a high statistical support ( $p p=0.99)$, this group was recovered as monophyletic and is made up mainly of Andean species: C. montivagus and C. evaristoi, from Ecuador, and C. thomasi and Cryptotis sp., from Colombia (Figure 4). An aspect worth mentioning is that a species from Central America (Cryptotis gracilis), supposedly with a morphology akin to the "goldmani" group, is closely related to the two Colombian species. Likewise, contrary to the morphological definition of this group, another Colombian species (C. squamipes) and an Ecuadorian species (C. niausa) were recovered as sister lineages ( $p p=0.99)$ and were unexpectedly associated with some members of the "mexicanus" group. Considering these findings and the fact that the mitochondrial topology of the work of Moreno-Cárdenas (2017) reports a relationship with low support ( $\mathrm{pp}=0.60$ ) between $C$. niausa and other members of the "nigrescens" group, it is reasonable to hypothesize that $C$. niausa, as well as $C$. squamipes and possibly also C. gracilis, are "relict species". However, this assumption requires further data to establish whether or not these are associated with the Cryptotis morphological groups currently defined.

The phylogenetic analyses and genetic distances of $C y t b$ support the taxonomic identity of the three Colombian species, while reflecting a pattern of affinity based on geographic proximity. Cryptotis sp. and C. thomasi, both sister

Table 5. Species richness of shrews (Cryptotis) in South American countries. *Likely presence in Colombia.

\begin{tabular}{|c|c|c|c|}
\hline Country & $\begin{array}{l}\text { Number of } \\
\text { species }\end{array}$ & Endemic & Non-endemic \\
\hline Colombia & 7 & $\begin{array}{l}\text { 5: brachyonyx, colombianus, } \\
\text { medellinius, squamipes, } \\
\text { thomasi }\end{array}$ & perijensis, tamensis \\
\hline Venezuela & 6 & $\begin{array}{l}\text { 4: aroensis, dinirensis, } \\
\text { meridensis, venezuelensis }\end{array}$ & perijensis, tamensis \\
\hline Ecuador & 4 & 3: equatoris*, niausa*, osgoodi & noctivagus \\
\hline Peru & 3 & 2: evaristoi, peruviensis & noctivagus \\
\hline
\end{tabular}

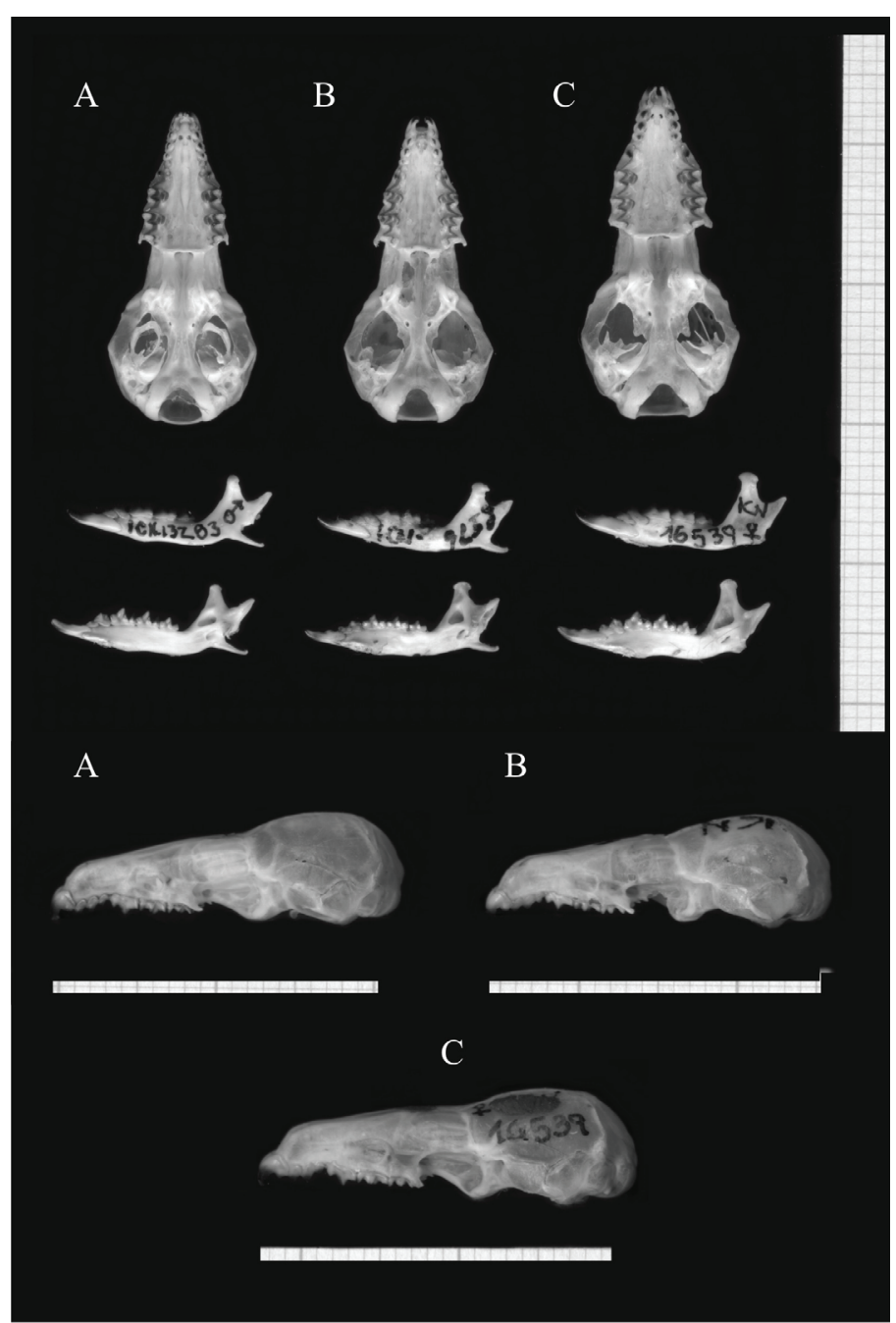

Figure 5. Details of the skull: A. Cryptotis from the department of Nariño. B. Cryptotis thomasi, C. Cryptotis cf. colombianus.

species within the "thomasi" group and distributed in the Eastern Cordillera of Colombia, exhibit a distance of $8.7 \%$ between them (Table 4). Similarly, C. squamipes differed from its Ecuadorian sister species ( $C$. niausa) by an average distance of $9.8 \%$ and both are distributed in the orographic region shared between the southwest of Colombia and northern Ecuador. The differences between these three Colombian species and the other species of Cryptotis involve a distance that exceeds $12 \%$.

\section{Discussion}

In general, the topics least addressed for Colombian shrews include ecology, natural history, systematics, biogeography, and genetics. We have identified research needs in nearly all topics evaluated, mainly in ecology, genetics, and molecular techniques (Table 1). The lack of molecular studies is partly due to the lack of joint efforts to conduct the molecular characterization of the species distributed in Colombia, as well as regarding policies dealing with access to these resources from the national government. This has led to a lag relative to other South American countries that are home to a lower diversity of shrews (Moreno-Cárdenas 2017; Zeballos et al. 2018). The lack of information 
about natural history and ecology partly results from the lack of implementation of appropriate methods to study shrews in the field coupled with the absence of research lines designed to that end. There are four priority areas of research for the species of shrews in Colombia.

Species Richness and Systematics. The lack of phylogenies involving all species living in Colombia and the missing morphological information associated with molecular analyses to support proper identification of voucher specimens in national collections have limited the understanding of species richness and distribution. Although Colombia is a country rich in shrew species relative to other South American countries (Table 5; Solari et al. 2013; Quiroga-Cardona and DoNascimiento 2016; Moreno Cárdenas and Román-Carrión 2017; Zeballos et al. 2018), this number appears to be underestimated, given the complexity of the Andean ecosystems. For example, there are reports on the presence of Cryptotis specimens lacking the morphological traits of the species known for the Central Cordillera (Sánchez and Alvear 2003; Rojas-Díaz et al. 2012; Figure 5). At least two of the known species in the country (e. g., C. squamipes and C. medellinius) may actually be species complexes (Woodman and Péfaur 2008). Furthermore, the presence of $C$. equatoris in Colombia is a subject that warrants further analysis.

Specimens tentatively identified as C. equatoris from the southwest of Colombia and deposited in Universidad de Nariño (PSO-CZ 483, 516) were collected at localities adjacent to those where this species was recorded in Ecuador (Moreno Cárdenas and Albuja V. 2014). The specimens are dark colored, similar to literature reports for $C$. equatoris and C. osgoodi (Moreno Cárdenas and Albuja V. 2014). Likewise, there are specimens from the department of Nariño deposited at the Institute of Natural Sciences, Universidad Nacional de Colombia (Figure 5a) and the PSO-CZ collection, which are grayish-brown, a color also observed in Ecuadorian species such as C. niausa (Moreno Cárdenas and Albuja V. 2014). However, a reevaluation of these specimens is required in accordance with the characteristics proposed in recent reviews (Moreno Cárdenas and Albuja V. 2014; Moreno Cárdenas and Román-Carrión 2017; Zeballos et al. 2018). If these records were confirmed with molecular information, the richness of shrews in Colombia would increase to nine species, with the possibility of an additional one, seemingly not described yet and discussed below.

Considering the availability of molecular information on shrews from North and Central America, as well as those inhabiting Ecuador and Peru, the inclusion of the Colombian species is necessary to understand aspects of the evolution and diversification of Cryptotis, especially in the ecosystems of the northern Andes of South America. The present work accomplishes the characterization of only two species out of seven knowns to inhabit in Colombia, in addition to a third with a questionable taxonomic determination. The latter, collected in ecosystems in the municipality of Santa Bárbara, department of Santander, shows a distribution adjacent to that of $C$. tamensis and close to that of $C$. meridensis, but exhibits a distinctive morphology. Molecular analyses of the three species will likely reveal the influence of either ecological mechanisms - as C. tamensis inhabits mainly forests while Cryptotis sp. has been collected in moorlands - or vicariant processes, as the ranges of C. meridensis and Cryptotis sp. are apparently separated by the Táchira depression, which would have led to the genetic differentiation between them.

The inclusion of C. thomasi, Cryptotis sp., and C. squamipes within a phylogenetic context of the genus sets the basis for further studies to elucidate aspects currently unknown. Particularly, C. squamipes, traditionally considered as a member of the "thomasi" group, seems to be a "relict species" along with C. niausa, without a clear association to any of the species groups defined based on morphological traits. This, coupled with the fact that the "mexicanus" and "goldmani" groups were not recovered as monophyletic, supports the contradiction observed between morphology and molecular characteristics. In this sense, the groups of species within Cryptotis should be reevaluated in light of new evidence, which will be partly achieved through the characterization of various molecular markers in a larger number of species.

Biogeography. Another area that deserves research on the shrews of Colombia is biogeography. The geographic information about the shrews in Colombia is heterogeneous and biased for most species (e. g., some records reported for $C$. thomasi are located outside of the Andean ecosystems; Figure 1). In general, the online databases have biases, errors, and lack of information associated with some specimens (Noguera-Urbano and Escalante 2014). In the case of the shrews of Colombia, the analysis of the geographic evidence (distribution maps and localities from databases) reveals little consistency between data sources. For this reason, the estimated distribution may be questionable for some of these species. This finding evidences the need to conduct reviews of the genus including all the specimens deposited in the various collections, both in the country and abroad. Some progress has been made on this topic (Estupiñán-Saavedra 2009; Marín Cardona 2009). The research priorities in this area include explorations in mountainous places where no shrews have been recorded, together with filtering and release of field information, and the evaluation of morphological and molecular traits to allow the identification both in the field and in the laboratory. This information will yield a better picture on the distribution of the species of shrews of Colombia.

Distribution maps are currently available for six of the seven species reported in Colombia. We believe that this may be due to the speed of information updating on the distribution of mammals. C. perijensis is a species described just recently (Quiroga Carmona and Woodman, 2015); this information is expected to be available soon in databases, and the recorded localities will likely increase. The growing knowledge about the distribution of species will improve management and decision-making in the conservation 
of shrew species (Guevara et al. 2015). In addition, there are spatial inconsistencies between records and distribution maps available in databases. For example, the distribution proposed for C. squamipes by IUCN and Woodman and Péfaur (2008) indicates that this species is distributed from Nariño to southern Tolima or the center of the Valle del Cauca, respectively. On the other hand, GBIF records indicate that this species is distributed from Cauca to the north of Valle del Cauca, and only one record overlaps the distribution map.

The number of records available for the different species has increased since the proposals of Woodman and Péfaur (2008). However, this increase in the number of records does not involve data quality. This is evident in the outdated scientific names associated with the records or the absence of the specific name for some of those records. Therefore, the information on the distribution and sites of sympatry of shrew species should be updated and verified, since estimates derived from uncertain distributions cast doubts as to their interpretation.

The adaptation of shrews to Andean ecosystems point to the need to improve the conservation strategies in these areas, considering that this region is subject of the highest transformation rates in forest environments (Cavelier and Etter 1995; Rangel 2000; Armenteras et al. 2003) and the highest vulnerability to the impacts derived from the rising temperature. However, the overlap of distribution ranges with at least ten conservation areas of Colombia is highly likely, as these species inhabit mostly high-mountain areas in the country (Woodman and Péfaur 2008). Their presence in these areas involve new management challenges, given the little natural connectivity between high-mountain areas as a consequence of human activities.

Ecology and Natural History. It has been shown that shrews comprise an important component in the diet of carnivores and birds of prey. In particular, they are among the most common preys in the diet of owls (Tyto; Delgado-V. and Ramírez 2009). Despite the importance of the records of shrews obtained from food pellets, mainly of nocturnal birds of prey in Colombia, the absence of well-defined cranio-dental and postcranial traits restrain our ability to identify bone fragments to species. In addition, this limitation affects our understanding of the interactions between shrews and their predators.

The lack of knowledge on the natural history and ecology of shrews is a concern. Filling these information gaps requires the conduction of field monitoring and compilation of data associated with voucher specimens deposited in biological collections, especially as regards reproductive seasons, local abundances, and ecological interactions (i. e., parasites).

Conservation Status. Although no focal studies are currently available on the conservation status of the shrews of Colombia, several general threats have been identified that may affect the populations inhabiting the country. As regards the threats that shrews currently face, these species are highly sensitive to any alterations to high-mountain ecosystems, including both the transformation of ecosystems and deforestation, and the impacts of climate change. For example, the Andean forest and páramos show a tendency to shrink as a result of climatic variations; thus, páramos in Colombia currently represent $5 \%$ of the original area (Flantua et al. 2014; Hazzi et al. 2018). This reduction related to climatic variations poses risks to shrews because the reduction of ecosystems translates into smaller distribution areas of the associated flora and fauna. If it is considered that high-mountain ecosystems reached up to 1,900 or $2,200 \mathrm{~m}$ a.s.l. during glacial periods of the Quaternary (Hooghiemstra 2006; van der Hammen et al. 1974; Jimenez-Rivillas et al. 2018), an overall reduction in the sizes of populations of all species of Cryptotis can be inferred. However, further studies including the review of localities, research on fossils, phylogeographic analysis, and modeling of distribution ranges may support this hypothesis.

\section{Acknowledgments}

HERC thanks Universidad de Caldas (Project 0223418 "State of Knowledge and Phylogenetic Position of Small Mammals Endemic to Colombia: Evolutionary Relationships and Biogeographical Patterns"), and to the Rufford Small Grants (Grant 23710-1) for the support received for the elaboration of this document. To the initiative of the Sociedad Colombiana de Mastozoologia and BioModelos of the Instituto Humboldt for the study of the distributions of endemic mammals of Colombia. To the Biological Collections that provided information on the shrews of Colombia, especially to P. Rivas (MHNUC), Y. Muñoz (ICN), and H. Lopez (ICN). JEC is grateful to the Santander government, Instituto Alexander von Humboldt and the Universidad Industrial de Santander for management and implementation of the Santander BIO Project, which yielded information on specimen UIS-MZ-1594 (Cryptotis sp.). HERC and JEC thank L. Guevara for advisory during the processing of genetic material from the specimens of Colombia. In addition, our gratitude to two anonymous reviewers for their contributions to this manuscript. María Elena Sánchez Salazar translated the manuscript to English.

\section{Literature cited}

Abramov, A. V., A. A. Bannikova, D. M. Chernetskaya, V. S. Lebedev, and V. V. Rozhnov. 2017. The first record of Episoriculus umbrinus from Vietnam, with notes on the taxonomic composition of Episoriculus (Mammalia, Soricidae). Russian Journal of Theriology 16:117-128.

Alberico, M., A. Cadena, J. Hernández-Camacho, and Y. Muñoz-Saba. 2000. Mamíferos (Synapsida: Theria) de Colombia. Biota Colombiana 1:43-75.

Allen, J. A. 1912. Mammals from western Colombia. Bulletin of the American Museum of Natural History 31:71-95.

Allen, G. M. 1923. A new shrew from Colombia. Proceedings of the New England Zoological Club 8:37-38.

Altschul, S.F., W. Gish, W. Miller, E.W. Myers, and D.J. Lipman. 1990. Basic Local Alignment Search Tool. Journal of Molecular Biology 215:403-410. 
Andrade-Ponce, G., S. M. Montaño-Salazar, L. M. Riveros-Loaiza, H. E Ramírez-Chaves, and A. F. Suárez-Castro. 2016. Estado de conocimiento y prioridades de investigación de las familias Canidae, Mephitidae y Procyonidae (Mammalia: Carnivora) en Colombia. Revista de la Academia Colombiana de Ciencias Exactas, Físicas y Naturales 40:500-513.

Armenteras, D., F. Gast, and H. Villareal. 2003. Andean forest fragmentation and the representativeness of protected natural areas in the eastern Andes, Colombia. Biological Conservation 113:245-256.

Baird, A.B., T.J. McCarthy, R.G. Trujillo, Y.Y. Kang, M. Esmaeiliyan, J. Valdez, N. Woodman, and J.W. Bickham. 2018. Molecular systematics and biodiversity of the Cryptotis mexicanus group (Eulipotyphla: Soricidae): two new species from Honduras supported. Systematics and Biodiversity 16:108-117.

Bannikova, A. A., A. V. Abramov, V. S. Lebedev, and B. I. Sheftel. 2017. Unexpectedly high genetic diversity of the Asiatic shorttailed shrews Blarinella (Mammalia, Lipotyphla, Soricidae). Doklady Biological Sciences 474:93-97.

BRANT, S.V., AND G. ORTí. 2002. Molecular phylogeny of shorttailed shrews, Blarina (Insectivora: Soricidae). Phylogenetics and Evolution 22:163-173.

Cáceres Martínez, C. H., A. A. Acevedo, and J. F. González-Maya. 2017. A hundred years later: new record of the rare Cryptotis tamensis (Soricidae: Mammalia) from Tama National Natural Park, Colombia. Mammalogy Notes 4:30-31.

Castaño, J. H., Y. Muñoz-Saba, J. E. Botero, and J. H. Vélez. 2003. Mamíferos del Departamento de Caldas - Colombia. Biota Colombiana 4:247-259.

Castaño, J. H., D. A. Torres, V. Rojas-Díaz, C. A. Saavedra-Rodríguez, And J. Pérez-Torres. 2017. Mamíferos del departamento de Risaralda, Colombia. Biota Colombiana 18:239-254.

Castaño S., J. H. 2012. Mamíferos de Caldas: Un análisis de vacíos de información. Boletín Científico, Centro de Museos, Museo de Historia Natural 16:101-119.

Castiglia, R., F. Annesi, And G. Amori. 2007. Mitochondrial DNA reveals different phylogeographic structures in the water shrews Neomys anomalus and $N$. fodiens (Insectivora: Soricidae) in Europe. Journal of Zoological Systematics and Evolutionary Research 45:255-262.

Cavelier, J., AND A. EtTer. 1995. Deforestation of Montane Forest in Colombia as result of illegal plantations of opium (Papaver somniferum). Pp: 541-549 in Biodiversity and Conservation of Neotropical montane forests (Churchill, S. P., Baslev, H., Forero, E., and Luteyn, J. L., eds.). The New York Botanical Garden, New York.

Chen, Z. Z., K. He, C. Huang, T. Wan, L. K. Lin, S. Y. Liu, and X. L. Jiang. 2017. Integrative systematic analyses of the genus Chodsigoa (Mammalia: Eulipotyphla: Soricidae), with descriptions of new species. Zoological Journal of the Linnean Society 180:694-713.

Corredor-Carrillo, D. A., and Y. Muñoz-Saba. 2007. Mamíferos de la alta montaña de Perijá. Pp. 221-233 in Colombia, diversidad biótica $V$, la alta montaña de la Serranía de Perijá (Rangel-Ch, J. O. Ed.). Universidad Nacional de Colombia, Bogotá, Colombia.

Cuartas-Calle, C. A., and J. Muñoz-Arango. 2003. Marsupiales, cenoléstidos e insectívoros de Colombia. Editorial Universidad de Antioquia. Medellín, Colombia.
Cuervo Díaz, A., J. Hernández-Camacho, and A. Cadena G. 1986. Lista actualizada de los mamíferos de Colombia. Anotaciones sobre su distribución. Caldasia 15:471-501.

Choate, J. R., and E. D. Fleharty. 1973. Habitat preference and spatial relations of shrews in a mixed grassland in Kansas. The Southwestern Naturalist 18:110-112.

Darriba, D., G. L. Taboada, R. Doallo, and D. Posada. 2012. jModelTest 2: more models, new heuristics and parallel computing. Nature Methods 9:772.

Delgado-V., C. A. 2002. Food habits and habitat of the crabeating fox Cerdocyon thous in the highlands of eastern Antioquia Dept., Cordillera Central, Colombia. Mammalia 66: 603-605.

Delgado-V., C. A. 2009. Non-volant mammals, Reserva San Sebastián-La Castellana, Valle de Aburrá, Antioquia, Colombia. Check List 5:1-4.

Delgado-V., C. A., and J. D. Ramírez. 2009. Presas de la lechuza común (Tyto alba) en Jardín, Antioquia, Colombia. Ornitología Colombiana 8:88-93.

Diaz-Pulido, A., V. Rojas-Díaz, and C. A. Saavedra-Rodríguez. 2015. Mamíferos. Pp. 128-139 in Catálogo de biodiversidad para las regiones andina, pacífica y piedemonte amazónico. nivel regional. volumen 2 tomo 1. (Portocarrero-Aya, M., G. Corzo, and M. E. Chaves, eds.). Serie Planeación ambiental para la conservación de la biodiversidad en las áreas operativas de Ecopetrol. Proyecto Planeación ambiental para la conservación de la biodiversidad en las áreas operativas de Ecopetrol. Instituto de Investigación de Recursos Biológicos Alexander von Humboldt - Ecopetrol S. A. Bogotá D. C., Colombia.

Duarte, M. A., AND A. L. Vilora. 1992. Nuevo hallazgo de Cryptotis thomasi (Merriam, 1897) (Mammalia: Insectívora) en la Sierra de Perijá, Noreste de Colombia. Acta Científica Venezolana 43:240-242.

EDGAR, R. C. 2004. MUSCLE: multiple sequence alignment with high accuracy and high throughput. Nucleic Acids Research 32:1792-1797.

Escobar-Lasso, S., J. Cerón-Cardona, and J. H. Castaño-Salazar. 2013. Los mamíferos de la cuenca del río Chinchiná, en la región andina de Colombia. Therya 4:139-155.

ESRI. 2016. ArcGIS Desktop: Release 10. Redlands, CA: Environmental Systems Research Institute.

EstupiñÁN-SAAVEDRA, E. 2009. Revisión preliminar de la morfológia y morfometría de las musarañas del grupo Cryptotis thomasi (Soricomorpha: Soricidae) de la cordillera Oriental de Colombia. Trabajo de grado en Biología, Facultad de Ciencias, Escuela de Biología, Universidad Industrial de Santander, Colombia.

Flantua, S., H. Hooghiemstra, J. H. Van Boxel, M. Cabrera, Z. GonzálezCarranza, And C. González-Arango. 2014. Connectivity dynamics since the Last Glacial Maximum in the northern Andes: a pollen-driven framework to assess potential migration. Pp. 98-123 in Paleobotany and Biogeography: a festschrift for Alan Graham in his $80^{\text {th }}$ year (Stevens, W., O. Montiel, and P. Raven, eds.). St. Louis: Missouri Botanical Garden.

GBIF. 2018. GBIF Home Page. Disponible en: https://www.gbif. org. Downloaded on 28 November 2017.

Guevara López, L. 2010. Relaciones filogenéticas entre musarañas del grupo de especies Cryptotis mexicana 
(Mammalia: Soricomorpha). Tesis de Maestría, Posgrado en Ciencias Biológicas, Instituto de Biología, Universidad Nacional Autónoma de México.

Guevara, L., and F. A. Cervantes. 2014. Molecular systematics of small-eared shrews (Soricomorpha, Mammalia) within Cryptotis mexicanus species group from Mesoamérica. Acta Theriologica 59:233-242.

Guevara, L., F. A. Cervantes, and V. Sánchez-Cordero. 2015. Riqueza, distribución y conservación de los topos y las musarañas (Mammalia, Eulipotyphla) de México. Therya, 6:43-68.

Gutiérrez, E. E., K. M. Helgen, M. M. McDonough, F. Bauer, M. T. R. Hawkins, L. A. Escobedo-morales, B. D. Patterson, and J.E. MALDONADO. 2017. A gene-tree test of the traditional taxonomy of American deer: the importance of voucher specimens, geographic data, and dense sampling. ZooKeys 697:87-131.

Hazzi, A. N., J. S. Moreno, C. Ortiz-Movliav, and R. D. Palacio. 2018. Biogeographic regions and events of isolation and diversification of the endemic biota of the tropical Andes. Proceedings of the National Academy of Sciences 115:7985-7990.

HE, K., Y. J. LI, M. C. Brandley, L. K. Lin, Y. X. WANG, Y. P. Zhang, AND X. L. JIANG. 2010. A multi-locus phylogeny of Nectogalini shrews and influences of the paleoclimate on speciation and evolution. Molecular Phylogenetics and Evolution 56:734-746.

He, K., N. Woodman, S. Boaglio, M. Roberts, S. Supekar, and J. E. MALDONADO. 2015. Molecular phylogeny supports repeated adaptation to burrowing within small-eared shrews genus of Cryptotis (Eulipotyphla, Soricidae). PLoS ONE 10: e0140280.

HIJMANS, R. J. 2018. raster: geographic data analysis and modeling. R package ver. 2.6-7. http://CRAN.R-project.org/ package $=$ raster.

Hooghiemstra, H., V. M. WiJninga, and A. M Cleef. 2006. The paleobotanical record of Colombia: Implications for biogeography and biodiversity 1. Annals of the Missouri Botanical Garden 93:297-325.

IRWIN, D. M., T. D. KOCHER, AND A. C. WILSON. 1991. Evolution of the Cytochrome b gene of mammals. Journal of Molecular Evolution 32:128-144.

IUCN. 2018. The IUCN Red List of Threatened Species 2008: e.T136736A4333708. Disponible en: https://www.iucnredlist. org/resources/spatial-data-download. Downloaded on 28 September 2017.

Jiménez-Rivillas, C., J. J. García, M. A. Quijano-Abril, And J. M. Daza. 2018. A new biogeographical regionalisation of the Páramo biogeographic province. Australian Systematic Botany 31:296-310.

KIMURA, M. 1980. A simple method for estimating evolutionary rate of base substitutions through comparative studies of nucleotide sequences. Journal of Molecular Evolution 16: 111-120.

Kumar, S., G. Stecher, and K. Tamura. 2015. MEGA 7: Molecular Evolutionary Genetics Analysis version 7.0 for bigger datasets. Molecular Biology and Evolution 33:1870-1874.

Liévano Latorre, L. F., and H. F. López Arévalo. 2015. Comunidad de mamíferos no voladores en un área periurbana andina, Cundinamarca, Colombia. Acta Biológica Colombiana 20:193-202.

López-Arévalo, H., O. Montenegro-Díaz, and A. Cadena. 1993. Ecología de los pequeños mamíferos de la Reserva Biológica
Carpanta, en la cordillera Oriental colombiana. Studies on Neotropical Fauna and Environment 28:193-210.

MADS - Ministerio del Ambiente y Desarrollo Sostenible. 2014. Resolución No. 0192, “Por la cual se establece el listado de las especies silvestres amenazadas de la diversidad biológica colombiana que se encuentran en el territorio nacional, and se dictan otras determinaciones". Bogotá, 10 de febrero de 2014, p. 1-36.

MADS - Ministerio del Ambiente y Desarrollo Sostenible. 2017. Resolución No. 1912, "Por la cual se establece el listado de las especies silvestres amenazadas de la diversidad biológica colombiana continental y marino costera que se encuentran en el territorio nacional, and se dictan otras disposiciones". Bogotá, 15 Sept 2017, p. 1-38. Disponible en: http://www.minambiente.gov.co/images/normativa/app/ resoluciones/75-res\%201912\%20de\%202017.pdf

Marín CaRDonA, D. 2009. Caracterización morfológica y morfométrica de las musarañas de orejas pequeñas del género Cryptotis (Mammalia: Soricomorpha) en la Cordillera Central colombiana. Trabajo de grado. Instituto de Biología, Universidad de Antioquia.

Medina, W., D. C. Macana García, and F. Sánchez. 2015. Aves y mamíferos de bosque altoandino-páramo en el páramo de Rabanal (Boyacá-Colombia). Revista Ciencia en Desarrollo 6:185-1982.

Meegaskumbura, S., M. Meegaskumbura, R. Pethiyagoda, K. Manamendra-ArachCHI, and C. J. Schneider. 2007. Crocidura hikmiya, a new shrew (Mammalia: Soricomorpha: Soricidae from Sri Lanka. Zootaxa 1665:19-30.

MERRIAM, C. H. 1897. Description of five new shrews from Mexico, Guatemala and Colombia. Proceedings of the Biological Society of Washington 11:227-230.

Moreno-CÁrdenAS, P. A. 2017. Sistemática y biogeografía de las musarañas del género Cryptotis (Eulipotyphla: Soricidae) en los andes de Ecuador. Tesis para optar al título de Máster en Biología de la Conservación. Escuela de Ciencias Biológicas, Facultad de Ciencias Exactas y Naturales, Pontificia Universidad Católica de Ecuador, Ecuador.

Moreno, P. A., AND L. Albuja V. 2014. Una nueva especie de musaraña del género Cryptotis Pomel 1848 (Mammalia: Soricomorpha: Soricidae) de Ecuador y estatus taxonómico de Cryptotis equatoris Thomas (1912). Papéis Avulsos de Zoologia 54:403-418.

Moreno Cárdenas, P. A., And J. L. Román-Carrión. 2017. Musarañas del género Cryptotis (Eulipotyphla: Soricidae) en el Pleistoceno Tardío de los Andes Ecuatorianos. Boletín de la Sociedad Geológica Mexicana 69:421-432.

Naylor, L., AND N. Roach. 2016a. Cryptotis medellinia. The IUCN Red List of Threatened Species 2016: e.T136267A22285456. http://dx.doi.org/10.2305/IUCN.UK.2016-2.RLTS. T136267A22285456.en. Downloaded on 15 January 2019.

NayloR, L., AND N. Roach. 2016b. Cryptotis squamipes. The IUCN Red List of Threatened Species 2016: e.T41378A22284402. http://dx.doi.org/10.2305/IUCN.UK.2016-2.RLTS. T41378A22284402.en. Downloaded on 13 October 2018.

Naylor, L., N. ROach, and M. Quiroga-Carmona. 2018. Cryptotis thomasi (amended version of 2016 assessment). The IUCN Red List of Threatened Species 2018: e.T41379A126907773. http://dx.doi.org/10.2305/IUCN. 
UK.2018-1.RLTS.T41379A126907773.en. Downloaded on 13 October 2018

Noguera-Urbano, E. A., And T. Escalante. 2014. Datos geográficos de los murciélagos (Chiroptera) en el Neotrópico. Revista de Biología Tropical 62:211-225.

Noguera-Urbano, E. A., And T. Escalante. 2015. Áreas de endemismo de los mamíferos (Mammalia) neotropicales. Acta Biológica Colombiana 20:47-65.

Ohdachl, S. D., M. Hasegawa, M. A. IWASa, P. Vogel, T. Oshida, L.-K. Lin, AND H. ABE. 2006. Molecular phylogenetics of soricid shrews (Mammalia) based on mitochondrial cytochrome $b$ gene sequences: with special reference to the Soricinae. Journal of Zoology 270:177-191.

Orlov, V. N., A. E. Balakirev, and Y. M. Borisov. 2011. Phylogenetic relationships of Caucasian shrew Sorex satunini Ogn. (Mammalia) in the superspecies Sorex araneus inferred from the data of karyological analysis and the mtDNA cyt b gene sequencing. Russian Journal of Genetics 47:711-719.

Otálora Ardila, A. 2003. Mamíferos de los bosques de roble. Acta Biológica Colombiana 8:357-371.

Pebesma, E. J., And R. S. Bivand. 2005. Classes and methods for spatial data in R. R News 5:9-13.

Pfau, R. S., D. B. Sasse, M. B. Connior, and I. F. Guenther. 2011. Ocurrence of Blarina brevicauda in Arkansas and notes on the distribution of Blarina carolinensis and Cryptotis parva. Journal of the Arkansas Academy of Sciences 65:61-66.

Quiroga-Cardona, M., And N. Woodman. 2015. A new species of Cryptotis (Mammalia, Eulipotyphla, Soricidae) from the Sierra de Perijá, Venezuelan-Colombian Andes. Journal of Mammalogy 96:800-809.

Quiroga-Cardona, M., And C. DoNascimiento. 2016. A new species of small-eared shrew of the genus Cryptotis Pomel, 1848 (Mammalia, Eulipotyphla, Soricidae) from the easternmost mountains of the Venezuelan Andes. Mammalian Biology 81:494-505.

R Development Core Team. 2018. R: A language and environment for statistical computing. $\mathrm{R}$ Foundation for Statistical Computing, Vienna, Austria. URL http://www.R-project.org/.

Rambaut, A., M. A. Suchard, D. Xie, and A. J. Drummond. 2014. Tracer v1.6. Disponible en: http://beast.bio.ed.ac.uk/Tracer

Ramírez-Chaves, H. E., and E. A. Noguera-Urbano. 2011. Lista preliminar de los mamíferos (Mammalia: Theria) del Departamento de Nariño - Colombia. Biota Colombiana 11:115-138. [fechado 2010, impreso 2011]

Ramírez-Chaves, H. E., A. F. Suárez-Castro, and J. F. González-Maya. 2016. Cambios recientes a la lista de mamíferos de Colombia. Mammalogy Notes 3:1-9.

RANGEL-CH, J. O. 2000. La región paramuna de Colombia y franjas aledañas. Pp. 1-23 in Colombia Diversidad Biótica III: La región de vida paramuna (Rangel-Ch, O., Ed). Instituto de Ciencias Naturales, Universidad Nacional de Colombia e Instituto Alexander von Humboldt, Bogotá.

Rivas-Pava, P., H. E. Ramírez-Chaves, Z. ÁlvareZ, and B. L. Niño-Valencia. 2007. Catálogo de los Mamíferos presentes en las colecciones de referencia y exhibición del Museo de Historia Natural de la Universidad del Cauca. Taller Editorial Universidad del Cauca, Popayán, Colombia.

Rojas-Díaz, V., M. Reyes-Gutiérrez, and M. S. Alberico. 2012. Mamíferos (Synapsida, Theria) del Valle del Cauca, Colombia. Biota Colombiana 13:99-116.
Ronguist, F., M. Teslenko, P. van der Mark, D. L. Ayres, A. Darling, S. Höhna, B. Larget, L. Liu, M. A. Suchard, And J. P. HuelsenbeCK. 2012. MrBayes 3.2: Efficient Bayesian phylogenetic tree inference and model choice across a large space. Systematic Biology 61:539-542.

SÁNCHEZ, F. 2000. Inventario de mamíferos en un bosque andino del departamento de Caldas, Colombia. Boletín Científico, Centro de Museos, Museo de Historia Natural 4:17-25.

Sánchez, F., and M. Alvear. 2003. Comentarios sobre el uso de hábitat, dieta, conocimiento popular de los mamíferos en un bosque andino de Caldas, Colombia. Boletín Científico, Centro de Museos, Museo de Historia Natural 7:122-144.

SiB Colombia. 2018. Portal de datos. Explora los datos. Disponible en: http://datos.biodiversidad.co. Downloaded on 28 November 2017.

SMith, M. F., AND J. L. PATTON. 1993. The diversification of South American murid rodents: Evidence from mitochondrial DNA sequence data for the akodontine tribe. Biological Journal of the Linnean Society 50:149-177.

Smith M. F., And J. L. Patton. 2003. Diversification of South American murid rodents: evidence from mitochondrial DNA sequence data for the akodontine tribe. Biological Journal of the Linnean Society 50:149-177.

Solari, S., J. M. Martínez-C., D. Marín-C., and E. Patiño C. 2015. Geographic patterns of Andean assemblages of small mammals from Antioquia, Colombia. Pp. 57 in 8 Congreso Brasileiro de Mastozoologia, SBMz 30 anos. Livro de resumos. João Pessoa, Brasil.

Solari, S., Y. Muñoz-Saba, J. V. Rodríguez-Mahecha, T. R. Defler, H. E. Ramírez-Chaves, and F. Trujillo. 2013. Riqueza, endemismo y conservación de los mamíferos de Colombia. Mastozoología Neotropical 20:301-365.

TATE, G. H. H. 1932. Distribution of the South American shrews. Journal of Mammalogy 13:223-228.

Thomas, O. 1921. New Cryptotis, Thomasomys, and Oryzomys from Colombia. The Annals and Magazine of Natural History 9:354-57.

VAN der Hammen, T. 1974. The Pleistocene Changes of Vegetation and Climate in Tropical South America. Journal of Biogeography 1:3-26

Vianchá Sánchez, A. P., J. Y. Cepeda-Gómez, E. C. Muñoz López, Á. M. Hernández Ochoa, and L. Rosero Lasprilla. 2012. Mamíferos pequeños no voladores del Parque Natural Municipal Ranchería, Paipa, Boyacá, Colombia. Revista Biodiversidad Neotropical 2:37-44.

Vivar, E., V. Pacheco, and M. Valqui. 1997. A new species of Cryptotis (Insectivora: Soricidae) from northern Peru. American Museum Novitates 3202:1-15.

Woodman, N. 1996. Taxonomic status of the enigmatic Cryptotis avia (Mammalia: Insectivora: Soricidae), with comments on the distribution of the Colombian small-eared shrew, Cryptotis colombiana. Proceedings of the Biological Society of Washington 109:409-418.

Woodman, N. 2002. A new species of small-eared shrew from Colombia and Venezuela (Mammalia: Soricomorpha: Soricidae: Genus Cryptotis). Proceedings of the Biological Society of Washington, 115:249-272.

Woodman, N. 2003. A new small-eared shrew of the Cryptotis nigrescens-group from Colombia (Mammalia: Soricomorpha: 
Soricidae). Proceedings of the Biological Society of Washington 116:853-872.

Woodman, N. 2008a. Cryptotis brachyonyx. The IUCN Red List of Threatened Species 2008: e.T136736A4333708. Disponible en: http://dx.doi.org/10.2305/IUCN.UK.2008. RLTS.T136736A4333708.en. Downloaded on 26 May 2017.

Woodman, N. 2008b. Cryptotis colombiana. The IUCN Red List of Threatened Species 2008: e.T136795A4340771. Disponible en: http://dx.doi.org/10.2305/IUCN.UK.2008. RLTS.T136795A4340771.en. Downloaded on 26 May 2017.

Woodman, N. 2017. Cryptotis colombiana. The IUCN Red List of Threatened Species 2017: e.T136795A22284247. Disponible en: $\quad$ http://dx.doi.org/10.2305/IUCN.UK.2017-2.RLTS. T136795A22284247.en. Downloaded on 9 September 2018.

WoOdMAN, N., AND R. M. TIMm. 1993. Intraspecific and interspecific variation in the Cryptotis nigrescens species complex of smalleared shrews (Insectivora: Soricidae), with the description of a new species from Colombia. Fieldiana: Zoology 74:1-30.

Woodman, N., AND S. A. GafFney. 2014. Can they dig it? Functional morphology and semifossoriality among small eared shrews, genus Cryptotis (Mammalia, Soricidae). Journal of Morphology 275:745-59.

Woodman, N., AND J. Péfaur. 2008. Order Soricomorpha Gregory, 1910. Pp. 177-187 in Mammals of South America, Volume 1. Marsupials, xenarthrans, shrews, and bats (Gardner, A. L., Ed.). The University of Chicago Press. Chicago, Illinois, U. S. A. [dated 2007, printed 2008]

Woodman, N., AND M. Quiroga-Carmona. 2018. Cryptotis tamensis (amended version of 2017 assessment). The IUCN Red List of Threatened Species 2018: e.T136780A126907401. Disponible en: http://dx.doi.org/10.2305/IUCN.UK.2018-1. RLTS.T136780A126907401.en. Downloaded on 15 January 2019.

Woodman, N., C. A. Cuartas-Calle, and C. A. Delgado-V. 2003. The humerus of Cryptotis colombiana and its bearing on the species' phylogenetic relationships (Soricomorpha: Soricidae). Journal of Mammalogy 84:832-839.

Zeballos, H., K. Pino, C. E. Medina, A. Pari, D. Chávez, N. Tinoco, and G. Ceballos. 2018. A new species of small-eared shrew of the genus Cryptotis (Mammalia, Eulipotyphla, Soricidae) from the northernmost Peruvian Andes. Zootaxa 4377:51-73.

Associated editor: Pablo Teta

Submitted: January 18, 2019; Reviewed: February 11, 2019;

Accepted: April 1, 2019; Published on line: May 26, 2019. 


\section{Appendix 1.}

List of sequences included in the phylogenetic and distance analyzes. Abbreviations: ASNHC (Angelo State Natural History collections, Angelo State University, San Angelo, Texas, USA), CNMA (National Collection of Mammals, Instituto de Biología, UNAM, México), CMNH (Carnegie Museum of Natural, History, Pittsburgh, Pennsylvania, USA), HA (Abe H private collection), ICN (Collection of Mammals, Instituto de Ciencias Naturales, Bogotá, Colombia), KIZ (Kunming Institute of Zoology, Kunming, China), KU (Kansas University Museum, USA), MVZ (The Museum of Vertebrate Zoology, Berkeley, USA), LACM (Natural History Museum of Los Angeles County, USA), MHNUC (Collection of Mammals, Museum of Natural History, Universidad del Cauca, Popayán, Colombia), MHP (Sternberg Museum of Natural History, Fort Hays State University, USA), MUSA (Museum of Natural History, Universidad Nacional de San Agustín, Perú), MVZ (Museum of Vertebrate Zoology at Berkeley, USA), QCAZ (Museum of Zoology, Pontificia Universidad Católica del Ecuador), ROM (Royal Ontario Museum, Canadá), TK (Natural Science Research Laboratory, Texas Tech University, USA), UIS-MZ (Collection of Mammals, Museum of Natural History, Universidad Industrial de Santander), USNM (National Museum of Natural History; Smithsonian Institution; Washington, DC, USA), ZIN (Zoological Institute of the Russian Academy of Sciences, Rusia).

\begin{tabular}{|c|c|c|c|c|c|}
\hline Taxón & Voucher & Código de acceso & Localidad & Cytb (pb) & Fuente \\
\hline Blarina brevicauda & USNM 569100 & KT876835 & USA: Pennsylvania & 1107 & He et al. (2015) \\
\hline Blarina brevicauda & USNM 569118 & KT876836 & USA: Virginia & 1107 & He et al. (2015) \\
\hline Blarina brevicauda & USNM 570202 & KT876837 & USA: Maine & 1107 & He et al. (2015) \\
\hline Blarina carolinensis & & JF912171 & & 452 & Pfau et al. (2011) \\
\hline Blarina carolinensis & TK164126 & JF912173 & USA: Arkansas & 452 & Pfau et al. (2011) \\
\hline Blarina hylophaga & MHP KK766 & JF912177 & & 452 & Pfau et al. (2011) \\
\hline Blarina hylophaga & MHP KK767 & JF912178 & & 452 & Pfau et al. (2011) \\
\hline Blarinella griselda & ZIN:97788 & KY249527 & Vietnam: Sa Pa & 1076 & Bannikova et al. (2017) \\
\hline Blarinella quadraticauda & & JF719721 & & 1140 & No published \\
\hline Chimarrogale himalayica & & AB107875 & Taiwán: Nantou & 1140 & Ohdachi et al. (2006) \\
\hline Chimarrogale platycephalus & HA7789* & AB108769 & Japón: Shiga & 1140 & Ohdachi et al. (2006) \\
\hline Chodsigoa parca & KIZ 201212894028696 & KX765508 & China: Yunnan & 1140 & Chen et al. (2017) \\
\hline Crocidura fuliginosa & MVZ186404 & EU122212 & Vietnam & 1140 & Meegaskumbura et al. (2007) \\
\hline Episoriculus leucops & HA7127 & AB175111 & Nepal: Syng Gomba & 1140 & Ohdachi et al. (2006) \\
\hline Episoriculus umbrinus & ZIN 96263 & MF577030 & Vietnam: Lao Cai & 1123 & Abramov et al. (2017) \\
\hline Megasorex gigas & LACM 055131 & AB175150 & México: Colima & 1140 & Ohdachi et al. (2006) \\
\hline Nectogale elegans & 19715 & GU981294 & China: Yunnan & 1140 & He et al. (2010) \\
\hline Neomys anomalus & & DQ991055 & España & 1140 & Castiglia et al. (2007) \\
\hline Notiosorex crawfordi & LACM LAF1313 & AB175148 & México: Baja California & 1140 & Ohdachi et al. (2006) \\
\hline Notiosorex crawfordi & LACM LAF1295 & AB175149 & México: Baja California & 1140 & Ohdachi et al. (2006) \\
\hline Sorex raddei & & GU827404 & Rusia:Vyselki & 1046 & Orlov et al. (2011) \\
\hline Sorex satunini & & GU827402 & Rusia:Vyselki & 1038 & Orlov et al. (2011) \\
\hline Sorex volnuchini & & GU827400 & Rusia:Vyselki & 1045 & No published \\
\hline Soriculus nigrescens & 19710 & GU981300 & China:Yunnan & 1140 & He et al. (2010) \\
\hline Soriculus nigrescens & 19711 & GU981301 & China: Yunnan & 1140 & He et al. (2010) \\
\hline Cryptotis alticola & CNMA 44765 & KF551854 & México: Zoquiapan & 1140 & Guevara and Cervantes (2014) \\
\hline Cryptotis alticola & CNMA 44766 & KF551855 & México: Zoquiapan & 1140 & Guevara and Cervantes (2014) \\
\hline Cryptotis alticola & CNMA 44768 & KF551856 & México: Zoquiapan & 1140 & Guevara and Cervantes (2014) \\
\hline Cryptotis celaque & CMNH SP13226 & MF158092 & & 1119 & Baird et al. (2018) \\
\hline Cryptotis celaque & CMNH SP13228 & MF158093 & & 1120 & Baird et al. (2018) \\
\hline Cryptotis celaque & CMNH SP13229 & MF158094 & & 1119 & Baird et al. (2018) \\
\hline Cryptotis celaque & CMNH SP13234 & MF158095 & & 1117 & Baird et al. (2018) \\
\hline Cryptotis evaristoi & MUSA 7428 & MH352617 & Perú: Cajamarca & 1116 & Zeballos et al (2018) \\
\hline Cryptotis goldmani & LACM LAF1596 & AB175136 & México: Guerrero & 1140 & Ohdachi et al. (2006) \\
\hline Cryptotis goldmani & LACM LAF1599 & AB175137 & México: Guerrero & 1140 & Ohdachi et al. (2006) \\
\hline Cryptotis goldmani & LACM LAF1595 & AB175138 & México: Guerrero & 1140 & Ohdachi et al. (2006) \\
\hline Cryptotis gracilis & USNM 568678 & KT876838 & Costa Rica: Cartago & 412 & He et al. (2015) \\
\hline Cryptotis lacertosus & USNM 569368 & KT876839 & Guatemala: Huehuetenango & 1107 & He et al. (2015) \\
\hline
\end{tabular}


Continue...

Cryptotis lacertosus

Cryptotis lacertosus

Cryptotis lacertosus

Cryptotis lacertosus

Cryptotis lacertosus

Cryptotis magna

Cryptotis magna

Cryptotis magna

Cryptotis mam

Cryptotis mam

Cryptotis mam

Cryptotis mam

Cryptotis mam

Cryptotis mam

Cryptotis mam

Cryptotis mam

Cryptotis mam

Cryptotis mayensis

Cryptotis mayensis

Cryptotis mayensis

Cryptotis mayensis

Cryptotis mccarthyi

Cryptotis mccarthyi

Cryptotis mccarthyi

Cryptotis merriami

Cryptotis merriami

Cryptotis merriami

Cryptotis merriami

Cryptotis merriami

Cryptotis merriami

Cryptotis mexicanus

Cryptotis mexicanus

Cryptotis mexicanus

Cryptotis mexicanus

Cryptotis mexicanus

Cryptotis mexicanus

Cryptotis mexicanus

Cryptotis mexicanus

Cryptotis montivagus

Cryptotis montivagus

Cryptotis montivagus

Cryptotis montivagus

Cryptotis nelsoni

Cryptotis nelsoni

Cryptotis nelsoni

Cryptotis nelsoni

Cryptotis nelsoni

Cryptotis niausa

Cryptotis niausa

Cryptotis niausa

Cryptotis niausa

Cryptotis nigrescens

Cryptotis obscurus

\begin{tabular}{|c|c|}
\hline USNM 569420 & KT876840 \\
\hline USNM 569431 & KT876841 \\
\hline USNM 569442 & KT876842 \\
\hline USNM 569443 & KT876843 \\
\hline USNM 569503 & KT876844 \\
\hline LACM LAF1514 & AB175139 \\
\hline LACM LAF1550 & $A B 175140$ \\
\hline LACM LAF1515 & AB175141 \\
\hline USNM 569554 & KT876845 \\
\hline USNM 569555 & KT876846 \\
\hline USNM 570248 & KT876847 \\
\hline USNM 570256 & KT876848 \\
\hline USNM 570257 & KT876849 \\
\hline USNM 570313 & KT876850 \\
\hline USNM 570314 & KT876851 \\
\hline USNM 570337 & KT876852 \\
\hline USNM 570340 & KT876853 \\
\hline ROM 96535-FN30563 & KT876854 \\
\hline CNMA:46150 & KF551857 \\
\hline CNMA:46151 & KF551858 \\
\hline CNMA:46152 & KF551859 \\
\hline CMNH SP12828 & MF158096 \\
\hline CMNH SP12836 & MF158097 \\
\hline CMNH SP12934 & MF158098 \\
\hline USNM 570108 & KT876855 \\
\hline USNM 570112 & KT876856 \\
\hline USNM 570122 & KT876857 \\
\hline USNM 570132 & KT876858 \\
\hline USNM 57049 & KT876859 \\
\hline USNM 570125 & KT876860 \\
\hline LACM LAF1506 & KT876861 \\
\hline LACM LAF1510 & AB127979 \\
\hline LACM LAF1509 & AB175142 \\
\hline LACM LAF1511 & AB175143 \\
\hline CNMA 41951 & KF551836 \\
\hline CNMA 43051 & KF551837 \\
\hline CNMA:43059 & KF551838 \\
\hline CNMA 43061 & KF551839 \\
\hline QCAZ 4996 & MH352622 \\
\hline QCAZ 4997 & MH352623 \\
\hline QCAZ 8409 & MH352620 \\
\hline QCAZ 12037 & MH352621 \\
\hline CNMA 41961 & KF551840 \\
\hline CNMA 41964 & KF551841 \\
\hline CNMA 41965 & KF551842 \\
\hline CNMA 41969 & KF551843 \\
\hline CNMA 41970 & KF551844 \\
\hline QCAZ 11246 & MH352619 \\
\hline QCAZ 12642 & MH352624 \\
\hline QCAZ 12650 & MH352625 \\
\hline QCAZ 12661 & MH352626 \\
\hline KU 143389 & KT876862 \\
\hline CNMA 42285 & KF551846 \\
\hline
\end{tabular}

Guatemala: Huehuetenango
Guatemala: Huehuetenango
Guatemala: Huehuetenango
Guatemala: Huehuetenango
Guatemala: Huehuetenango
México: Oaxaca
México: Oaxaca
México: Oaxaca
Guatemala: Huehuetenango
Guatemala: Huehuetenango
Guatemala: Huehuetenango
Guatemala: Huehuetenango
Guatemala: Huehuetenango
Guatemala: Huehuetenango
Guatemala: Huehuetenango
Guatemala: Huehuetenango
Guatemala: Huehuetenango
México: Campeche
México: Yucatán
México: Yucatán

1107

1107

1107

1107

1107

1140

1140

1140

1107

1107

1107

1107

1107

1107

1107

1107

1107

1107

1140

1140

1140

1120

1121

1120

Guatemala: Alta Verapaz

Guatemala: Alta Verapaz

Guatemala: Alta Verapaz

Guatemala: Alta Verapaz

Guatemala: Zacapa

Guatemala: Zacapa

México: Oaxaca

México: Oaxaca

México: Oaxaca

México: Oaxaca

México: Veracruz

México: Oaxaca

México: Oaxaca

México: Oaxaca

Ecuador: Azuay

Ecuador: Azuay

Ecuador: Chimborazo

Ecuador: Chimborazo

México: Veracruz

México: Veracruz

México: Veracruz

México: Veracruz

México: Veracruz

Ecuador: Carchi

Ecuador: Carchi

Ecuador: Carchi

Ecuador: Carchi

Costa Rica: Punta Arenas

México: Tlaxcala

1107

1107

630

1140

1140

1140

1140

1140

1140

1098

1080

1086

1119

1140

1140

1140

1140

1140

1119

1123

1123

714

815

1140
He et al. (2015)

He et al. (2015)

He et al. (2015)

He et al. (2015)

He et al. (2015)

Ohdachi et al. (2006)

Ohdachi et al. (2006)

Ohdachi et al. (2006)

He et al. (2015)

He et al. (2015)

He et al. (2015)

He et al. (2015)

He et al. (2015)

He et al. (2015)

He et al. (2015)

He et al. (2015)

He et al. (2015)

He et al. (2015)

Guevara and Cervantes (2014)

Guevara and Cervantes (2014)

Guevara and Cervantes (2014)

Baird et al. (2018)

Baird et al. (2018)

Baird et al. (2018)

He et al. (2015)

1107 He et al. (2015)

1107 He et al. (2015)

1107 He et al. (2015)

1107 He et al. (2015)
He et al. (2015)

He et al. (2015)

No published

Ohdachi et al. (2006)

Ohdachi et al. (2006)

Guevara and Cervantes (2014)

Guevara and Cervantes (2014)

Guevara and Cervantes (2014)

Guevara and Cervantes (2014)

Zeballos et al (2018)

Zeballos et al (2018)

Zeballos et al (2018)

Zeballos et al (2018)

Guevara and Cervantes (2014)

Guevara and Cervantes (2014)

Guevara and Cervantes (2014)

Guevara and Cervantes (2014)

Guevara and Cervantes (2014)

Zeballos et al (2018)

Zeballos et al (2018)

Zeballos et al (2018)

Zeballos et al (2018)

He et al. (2015)

Guevara and Cervantes (2014) 
Continue...

\begin{tabular}{|c|c|c|c|c|c|}
\hline Cryptotis obscurus & CNMA 44637 & KF551845 & México: Tamaulipas & 1140 & Guevara and Cervantes (2014) \\
\hline Cryptotis oreoryctes & USNM 569854 & KT876863 & Guatemala: Alta Verapaz & 1107 & He et al. (2015) \\
\hline Cryptotis oreoryctes & USNM 569877 & KT876864 & Guatemala: Alta Verapaz & 1107 & He et al. (2015) \\
\hline Cryptotis oreoryctes & USNM 569878 & KT876865 & Guatemala: Alta Verapaz & 1107 & He et al. (2015) \\
\hline Cryptotis orophilus & CMNH SP11644 & MF158113 & & 1080 & Baird et al. (2018) \\
\hline Cryptotis parvus & & AF395483 & & 1138 & Brant and Ortí (2002) \\
\hline Cryptotis parvus & & AF395484 & & 1138 & Brant and Ortí (2002) \\
\hline Cryptotis parvus & USNM 568660 & KT876866 & USA: Virginia & 1104 & He et al. (2015) \\
\hline Cryptotis parvus & USNM 569083 & KT876867 & USA: Virginia & 1103 & He et al. (2015) \\
\hline Cryptotis parvus & USNM 570487 & KT876868 & USA: Maryland & 774 & He et al. (2015) \\
\hline Cryptotis parvus & USNM 570510 & KT876869 & USA: Kansas & 1107 & He et al. (2015) \\
\hline Cryptotis parvus & ANSHC 8192 & AB175135 & USA:Texas & 1140 & Ohdachi et al. (2006) \\
\hline Cryptotis peregrinus & CNMA:45582 & KF551848 & México: Oaxaca & 1140 & Guevara and Cervantes (2014) \\
\hline Cryptotis peregrinus & CNMA:45583 & KF551849 & México: Oaxaca & 1140 & Guevara and Cervantes (2014) \\
\hline Cryptotis peregrinus & CNMA:45584 & KF551847 & México: Oaxaca & 1140 & Guevara and Cervantes (2014) \\
\hline Cryptotis phillipsii & CNMA:4469 & KF551850 & México: Oaxaca & 1140 & Guevara and Cervantes (2014) \\
\hline Cryptotis phillipsii & CNMA:44723 & KF551853 & México: Oaxaca & 1140 & Guevara and Cervantes (2014) \\
\hline Cryptotis phillipsii & CNMA:44724 & KF551852 & México: Oaxaca & 1140 & Guevara and Cervantes (2014) \\
\hline Cryptotis phillipsii & CNMA:44728 & KF551851 & México: Oaxaca & 1140 & Guevara and Cervantes (2014) \\
\hline Cryptotis tropicalis & USNM 570435 & KT876870 & Guatemala: Huehuetenango & 1107 & He et al. (2015) \\
\hline Cryptotis thomasi & $\mathrm{ICN}$ & MK681775 & Colombia: Cundinamarca & 1140 & This work \\
\hline Cryptotis squamipes & MHNUC 1572 & MK681776 & Colombia: Cauca & 1140 & This work \\
\hline Cryptotis sp. & UIS-MZ-1594 & MK681774 & Colombia: Santander & 1093 & This work \\
\hline
\end{tabular}


